\title{
MXene in the lens of biomedical engineering: synthesis, applications and future outlook
}

\author{
Adibah Zamhuri', Gim Pao Lim ${ }^{1}$, Nyuk Ling Ma ${ }^{3}$, Kian Sek Tee ${ }^{2}$ and Chin Fhong Soon ${ }^{1,2^{*}}$ (i)
}

\author{
*Correspondence: \\ soon@uthm.edu.my \\ ${ }^{1}$ Biosensor and Bioengineering \\ Lab, Microelectronics and \\ Nanotechnology-Shamsuddin \\ Research Centre, Institute \\ for Integrated Engineering, \\ Universiti Tun Hussein Onn \\ Malaysia, Parit Raja, 86400 Batu \\ Pahat, Johor, Malaysia \\ Full list of author information is \\ available at the end of the article
}

\begin{abstract}
MXene is a recently emerged multifaceted two-dimensional (2D) material that is made up of surface-modified carbide, providing its flexibility and variable composition. They consist of layers of early transition metals (M), interleaved with $n$ layers of carbon or nitrogen (denoted as $X$ ) and terminated with surface functional groups (denoted as $T_{X} /$ $T_{z}$ ) with a general formula of $M_{n+1} X_{n} T_{x}$ where $n=1-3$. In general, MXenes possess an exclusive combination of properties, which include, high electrical conductivity, good mechanical stability, and excellent optical properties. MXenes also exhibit good biological properties, with high surface area for drug loading/delivery, good hydrophilicity for biocompatibility, and other electronic-related properties for computed tomography (CT) scans and magnetic resonance imaging (MRI). Due to the attractive physicochemical and biocompatibility properties, the novel 2D materials have enticed an uprising research interest for application in biomedicine and biotechnology. Although some potential applications of MXenes in biomedicine have been explored recently, the types of MXene applied in the perspective of biomedical engineering and biomedicine are limited to a few, titanium carbide and tantalum carbide families of MXenes. This review paper aims to provide an overview of the structural organization of MXenes, different top-down and bottom-up approaches for synthesis of MXenes, whether they are fluorine-based or fluorine-free etching methods to produce biocompatible MXenes. MXenes can be further modified to enhance the biodegradability and reduce the cytotoxicity of the material for biosensing, cancer theranostics, drug delivery and bio-imaging applications. The antimicrobial activity of MXene and the mechanism of MXenes in damaging the cell membrane were also discussed. Some challenges for in vivo applications, pitfalls, and future outlooks for the deployment of MXene in biomedical devices were demystified. Overall, this review puts into perspective the current advancements and prospects of MXenes in realizing this 2D nanomaterial as a versatile biological tool.
\end{abstract}

Keywords: MXene, Biomedical application, Biosensors, Cancer theranostics, Drug delivery, Antimicrobial activity 


\section{Introduction}

Two-dimensional (2D) materials are currently of keen interest to material researchers due to their excellent electronic, mechanical, and optical properties. On the contrary, during early twentieth century, classical physicists predicted that the stability of $2 \mathrm{D}$ materials were thermodynamically ambiguous at any fixed temperature due to thermal lattice fluctuations [1]. Nevertheless, 2004 marked the scientific breakthrough in the world of material science with the discovery of 2D graphene monolayer [1]. Physically, 2D materials are atomically thin crystalline solids, bonded by covalent and van der Waals (vdW) bonding, since the discovery of graphene, more 2D materials such as boron nitride, metal oxides and chalcogenides have emerged from exfoliation of their respective 3D precursors [1, 2]. 2D nanomaterials are composed of layers with atomic- to nano-scale thicknesses, and they exhibit different novel properties compared to their 3D counterparts [3]. However, previous 2D nanomaterials are mainly used for fundamental and academic research [4]. Only just recently new materials have been introduced with greatly enhanced physical and chemical properties suitable for various research field [3, 5]. Electronic engineers are testing for energy storage systems and sensors [6, 7], and in more recent reports, they have been applied in bacterial cells and human cancer cells studies $[8,9]$.

"MXene" has emerged and acquired huge interest amongst the 2D nanomaterials research due to their modifiable chemical structures and exclusive characteristics. The first ever MXene was discovered by a group of researchers from Drexel University, Philadelphia, where they exfoliated 3D titanium aluminium carbide $\left(\mathrm{Ti}_{3} \mathrm{AlC}_{2}\right)$ or known as MAX phase using hydrofluoric acid (HF), and produced $2 \mathrm{D}$ titanium-carbide $\left(\mathrm{Ti}_{3} \mathrm{C}_{2}\right)$ layers [10]. MXenes are generally derived from transition metal carbides and nitrides [5]. MXenes, akin to graphene, are generally made from exfoliating their 3D precursors; this method is classified as a top-down approach. The 3D precursors for MXenes are called MAX phases, which are ternary carbides or nitrides with the general formula of $M_{n+1} A_{n}$. As shown in Fig. 1, $M$ is an early transition metal, $A$ is an A-group element (mostly main group IIIA or IVA), $\mathrm{X}$ is either carbon or nitrogen, and $n=1,2$ or 3 [3]. Because $\mathrm{M}-\mathrm{X}$ bonds are much stronger than $\mathrm{M}-\mathrm{A}$ bonds, and the A layers are chemically more active than $M-X$ layers, therefore, A layers can be selectively removed by a strong acid (i.e. hydrofluoric acid, HF) etching to produce $M_{n+1} X_{n}$ layers that can be further separated by sonication [6]. Through this etching process, the surfaces of MXenes are typically terminated with fluorine $(-\mathrm{F})$, hydroxide $(-\mathrm{OH})$ and oxygen $(-\mathrm{O})$ groups due to its high surface energy [3]. Therefore, the final chemical formula of MXene is summarised as $M_{n+1} X_{n} T_{x}$, where $T_{x}$ is the surface functional groups [6]. Till date, the most applied MXenes for biomedical and biotechnology are from the $\mathrm{Ti}_{3} \mathrm{C}_{2}$ and $\mathrm{Ti}_{2} \mathrm{C}$ groups. This opens up the opportunity to have new combinations of the $\mathrm{M}$ and $\mathrm{A}$ groups of elements other than Ti and C.

MXenes are characterised by numerous properties that are useful in their fundamental aspects such as structural, optical, electronic and even biological properties [11]. These properties enable them for a broad application, with the most recent one being in the biomedical field. The specific characteristics of MXenes include high surface area, presence of hydrophilic functional groups, high atomic numbers (for certain transition metals) and paramagnetic behaviour [11-14]. The functional groups on MXenes 


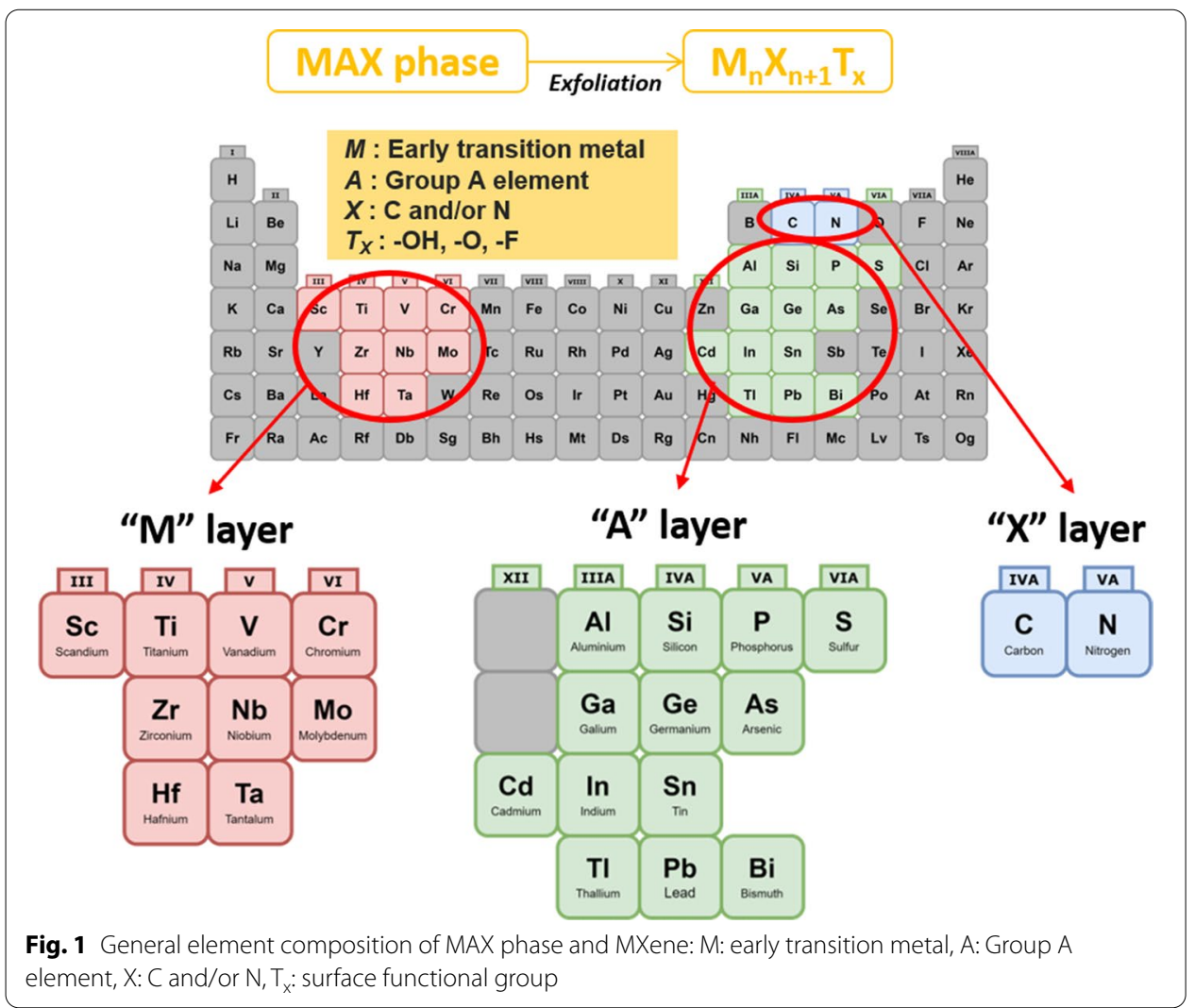

also contribute to their rigidness and flexibility, which is quite important in thin film formation as a part of bio-electronic devices [15]. MXene nanosheets exhibit high surface area, hence they are suitable for drug loading and delivery for theranostics applications and synergistic disease treatment $[13,16]$. The presence of hydrophilic functional groups is also important for drug loading/delivery, as the modification or functionalization increase biocompatibility for living cell/tissues [12]. The MXenes, consisting of high-atomic-number and paramagnetic transition metals, are more fitting for biomedical imaging, because they exhibit good X-ray attenuation for computed tomography (CT) scans and can be used as a magnetic resonance imaging (MRI) contrast agent [13]. Various types of MXenes could be synthesised based on different approaches, therefore, the biocompatibility assessment of MXene-based biomaterials is of utmost essential for overall biomedical applications.

For the past 6 years, there were a total of 121 publications on MXenes for biomedical applications reported in lens.org, searched with keywords "MXene" and "Biomedical" (Fig. 2). This amount of publication is relatively low for biomedical engineering compared to other well-known applications in electronics, catalysts and energy storage, which indicates that full potential of MXenes in biomedical applications remains scarce. Although research based on MXenes had been published since early 2012, MXene research on biomedical applications were only published 3 years later, since the first 3 years were dedicated to fundamental studies of MXenes, such as characterization of MXene structures to determine their properties. Research and studies on 2D MXenes for various types of biomedical applications are increasing, hence a comprehensive 


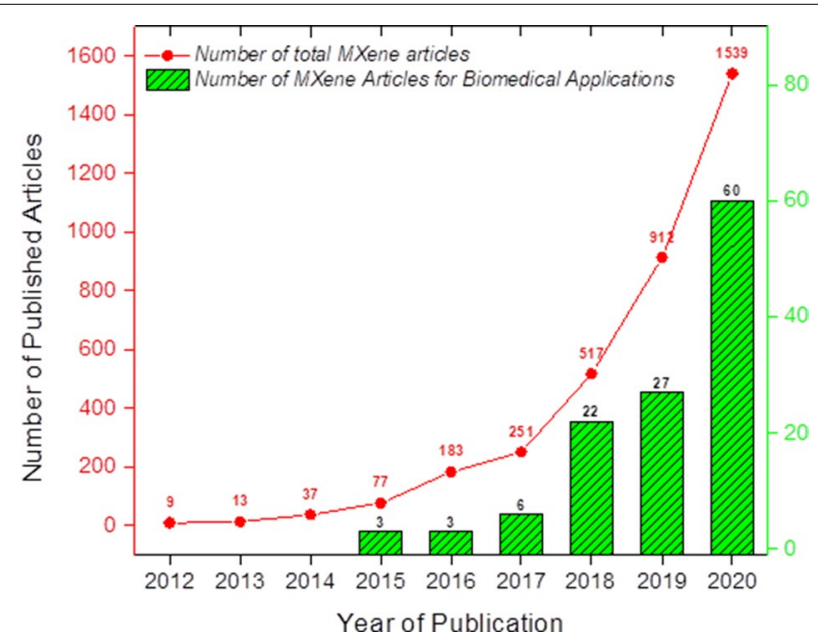

Fig. 2 Number of journal publications on MXenes for biomedical applications, searched with keywords "MXene" and "Biomedical" ( Source: lens.org, 2012 to 2020)

Table 1 Literature search results collected from lens.org

\begin{tabular}{lllllllll}
\hline Search terms & \multicolumn{9}{c}{ Number of journal articles published according to year } & \multirow{2}{*}{ Total articles } \\
\cline { 2 - 6 } & 2015 & 2016 & 2017 & 2018 & 2019 & 2020 & \\
\hline "MXene", "Biomedical" & 3 & 3 & 6 & 22 & 27 & 60 & 121 \\
"MXene", "Biosensors" & 2 & 2 & 1 & 7 & 17 & 30 & 59 \\
"MXene","Cancer theranostics" & - & - & 1 & 3 & 2 & 3 & 9 \\
"MXene", "Drug delivery" & - & - & 2 & 4 & 1 & 9 & 16 \\
"MXene","Antimicrobial" & 1 & - & - & 7 & 2 & 8 & 18 \\
\hline
\end{tabular}

review of MXenes for these applications is important for an overview and guidance for future research. The aim of this review is to highlight the key MXene synthesis technologies with top notch biomedical applications. The current challenges and future outlooks of biocompatible MXenes are also discussed. This review will be useful as a guidance for upcoming new research of MXenes for more advanced and diverse applications.

\section{Review methodology}

A systematic literature search was done to analyse published MXene papers from January 2015 to December 2020. Based on pre-selected criteria, appropriate research articles were selected using "lens.org". The metadata obtained from Lens.org are integrated from various sources that include PubMed, Crossref, Microsoft Academic, CORE, ORCID and PubMed Central. Relevant and recent articles are needed to justify the proposed contents and maintain the originality of this review. Initial screening of relevant literature included searching of articles related to the keywords of this review, i.e., MXene, biomedical application, biosensors, cancer theranostics, drug delivery, antimicrobial activity. The literature search results are summarized in Table 1. After reviewing and analysing suitable articles, the overall sections of the review were gathered and deliberated with relevant examples. 


\section{The Two Approaches for Synthesis MXene}

In general, MXenes can be synthesised by either bottom-up or top-down approaches. Choosing the appropriate approach is crucial to determine their overall physical and chemical properties, such as size, morphology and functionality of the material [17]. After synthesis (regardless of bottom-up/top-down), MXenes surface can be further modified to enhance the biocompatibility/reduce the cytotoxicity of the material for biomedical applications.

\section{Top-down approach}

The popular preparation method of MXene layers is the top-down fabrication approach initiated from MAX phase, which involves the acid exfoliation of layered A solids (Fig. 3). This method is considered as a classical method since the layered structure of MXene is similar to the structure of its 3D counterpart [14]. There are generally two steps: etching or cleavage of the MAX phase, and the delamination of the exfoliated MXene layers. For the synthesis of MAX phase, typically pristine powders of M, A and X in particular atomic ratios are mixed and heated to extreme high temperatures $\left(\sim 1200-1600{ }^{\circ} \mathrm{C}\right)$ [18]. The mixed sample will then be hot/cold pressed to densify the material and reduce microvoids or cracks in the material [19]. The pressure applied ( 25-45 MPa) during the hot/cold pressing will determine the grain growth orientation. One issue with this method is that excessive A element powder (e.g. Si or Al) is needed, since this powder easily evaporates and sucked into the vacuum/argon (Ar) atmosphere at high temperatures [17]. Another common method of MAX phase synthesis is by pressure-less sintering, where the combined MAX powders were simply heated to a certain temperature $[2,18]$. Pressure-less sintering was reported to produce highly oriented $\mathrm{Ti}_{3} \mathrm{AlC}_{2} \mathrm{MAX}$

\section{a Acid exfoliation synthesis process}

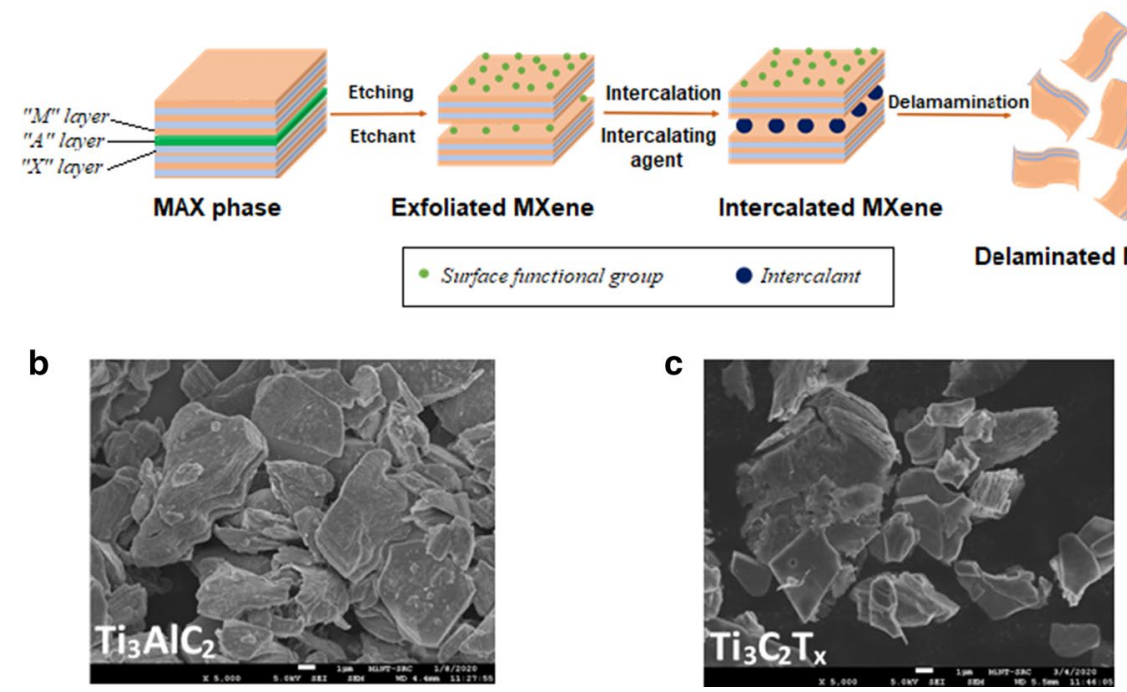

Fig. 3 a Schematic illustration of top-down MXene synthesis process (acid exfoliation method) based on the descriptions in [20], $\mathbf{b}$ FE-SEM images of $\mathrm{Ti}_{3} \mathrm{AlC}_{2} \mathrm{MAX}$ phase and $\mathbf{c} \mathrm{Ti}_{3} \mathrm{C}_{2} \mathrm{~T}_{x}$ MXene. FE-SEM images were obtained from Microelectronics and Nanotechnology-Shamsuddin Research Centre, Universiti Tun Hussein Onn Malaysia 
phase, compared to hot-pressed $\mathrm{Ti}_{3} \mathrm{AlC}_{2}$ [2]. However, this sintering limits the growth orientation of final MAX phase solids [17].

After the MAX phase is synthesised, the first synthesis step involves the etching of the 3D MAX phase such as $\mathrm{Ti}_{3} \mathrm{AlC}_{2}$ using a powerful etchant, usually HF [10]. M-A bonds are generally weaker than $\mathrm{M}-\mathrm{X}$ bonds, hence selective etching of the $\mathrm{M}-\mathrm{A}$ bonds is possible [25]. To etch the A-element from a common MAX phase, high concentration of fluoride ions $(\mathrm{F}-)$ must be involved, this is because $\mathrm{F}-$ ions bind strongly to the Aelement (or Al) [25]. Additionally, HF treatment of the MAX phase results in different surface terminations with $-\mathrm{OH},-\mathrm{O}$ and $-\mathrm{F}$ groups as shown in Fig. 4 [21]. Chemical Eqs. (1), (2) and (3) show the general chemical reactions of MAX phase $\left(M_{3} A X_{2}\right)$ with HF (aluminium was chosen as the A-layer) [10].

$$
\begin{aligned}
& \mathrm{M}_{\mathrm{n}+1} \mathrm{AlX}_{\mathrm{n}}(\mathrm{s})+3 \mathrm{HF}(\mathrm{aq}) \rightarrow \mathrm{M}_{\mathrm{n}+1} \mathrm{X}_{\mathrm{n}}(\mathrm{s})+\mathrm{AlF}_{3}(\mathrm{aq})+\frac{3}{2} \mathrm{H}_{2}(\mathrm{~g}) \\
& \mathrm{M}_{\mathrm{n}+1} \mathrm{X}_{\mathrm{n}}(\mathrm{s})+2 \mathrm{HF}(\mathrm{aq}) \rightarrow \mathrm{M}_{\mathrm{n}+1} \mathrm{X}_{\mathrm{n}} \mathrm{F}_{2}(\mathrm{~s})+2 \mathrm{H}_{2}(\mathrm{~g}) \\
& \mathrm{M}_{\mathrm{n}+1} \mathrm{X}_{\mathrm{n}}(\mathrm{s})+2 \mathrm{H}_{2} \mathrm{O}(\mathrm{aq}) \rightarrow \mathrm{M}_{\mathrm{n}+1} \mathrm{X}_{\mathrm{n}}(\mathrm{OH})_{2}(\mathrm{~s})+\mathrm{H}_{2}(\mathrm{~g}) .
\end{aligned}
$$

Previous studies as summarised in Table 2 have reported HF etching of MAX phases using different concentrations of HF with different immersion times and temperature $[10,16,22,23]$. The very first MXene synthesised by Naguib et al. involved immersing $\mathrm{Ti}_{3} \mathrm{AlC}_{2}$ powders in $50 \%$ concentrated $\mathrm{HF}$ at room temperature for $2 \mathrm{~h}$ to yield full dissociation of the MAX phase [10]. Other examples include $\mathrm{Ti}_{3} \mathrm{C}_{2}$ MXene production using

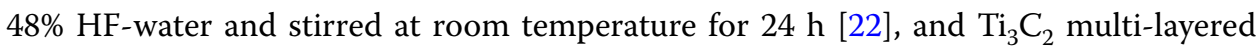
nanosheet production by stirring in $40 \% \mathrm{HF}$ at $45^{\circ} \mathrm{C}$ for 2 days [16].

Another most widely used etching method involves in situ formation of HF, where the reaction of an acid (e.g. hydrochloric acid, $\mathrm{HCl}$ ) and a fluoride salt forms upon $\mathrm{HF}$ mixing [13]. This method promotes safer etching of aluminium (Al) and avoids the harmful effects of concentrated HF. The first study on fluoride salt etching of MAX phase was using solution of lithium fluoride ( $\mathrm{LiF})$ and $\mathrm{HCl}$ with heating at $40^{\circ} \mathrm{C}$ for $45 \mathrm{~h}$ [23]. This

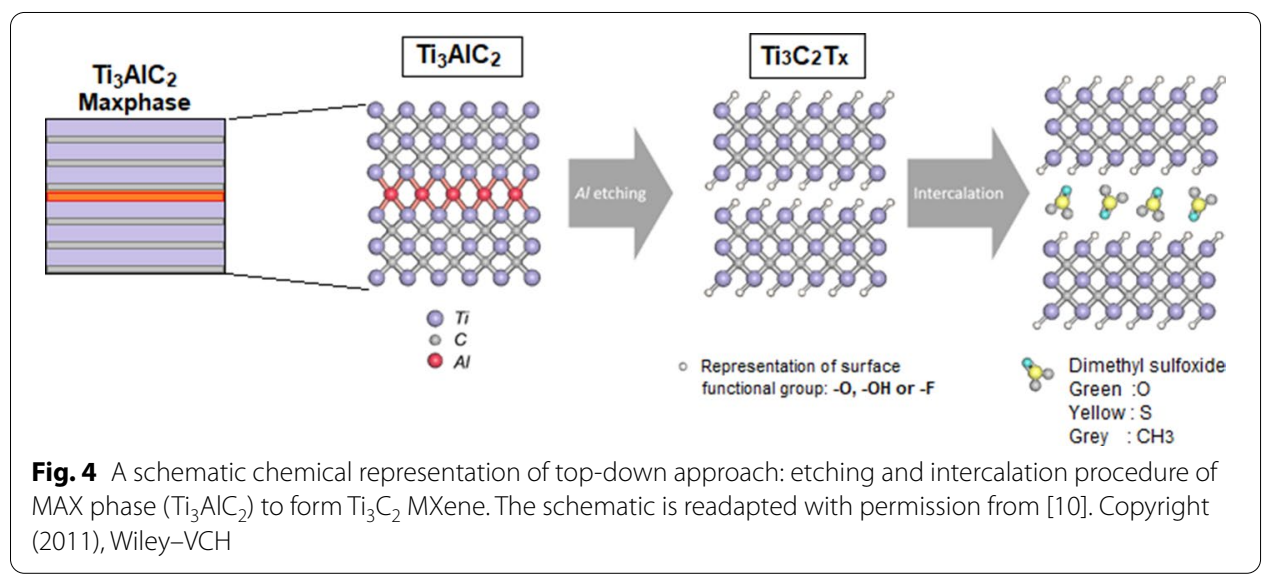


Table 2 Etching and intercalant conditions of MXene (top-down approach) synthesis as reported by several key studies

\begin{tabular}{|c|c|c|c|}
\hline MAX phase(s) & Etchant (conditions) & Intercalant (conditions) & Ref \\
\hline $\mathrm{Ti}_{3} \mathrm{AlC}_{2}$ & $50 \%$ HF $(2$ h, RT $)$ & - & [10] \\
\hline $\mathrm{Ti}_{3} \mathrm{AlC}_{2}$ & $48 \% \mathrm{HF}(24 \mathrm{~h}, \mathrm{RT})$ & TMAOH $(24 h, R T)$ & [22] \\
\hline $\mathrm{Ti}_{3} \mathrm{AlC}_{2}$ & $40 \% \mathrm{HF}\left(2\right.$ days, $\left.45^{\circ} \mathrm{C}\right)$ & TMAOH $\left(3\right.$ days, $\left.45^{\circ} \mathrm{C}\right)$ & {$[16]$} \\
\hline $\mathrm{Ti}_{3} \mathrm{AlC}_{2}, \mathrm{Ti}_{2} \mathrm{AlC}, \mathrm{Nb}_{2} \mathrm{AlC}$ & $\mathrm{LiF}+\mathrm{HCl}\left(45 \mathrm{~h}, 40^{\circ} \mathrm{C}\right)$ & - & [23] \\
\hline $\mathrm{Ti}_{3} \mathrm{AlC}_{2}$ & $\begin{array}{l}\mathrm{LiF}+\mathrm{HCl}\left(24 \mathrm{~h}, 50^{\circ} \mathrm{C}\right) \\
\mathrm{NH}_{4} \mathrm{~F}+\mathrm{HCl}\left(24 \mathrm{~h}, 30^{\circ} \mathrm{C}\right) \\
\mathrm{KF} / \mathrm{NaF}+\mathrm{HCl}\left(48 \mathrm{~h}, 40^{\circ} \mathrm{C}\right)\end{array}$ & $\begin{array}{l}- \\
- \\
-\end{array}$ & [24] \\
\hline $\mathrm{Ti}_{2} \mathrm{AlC}$ & $\begin{array}{l}\mathrm{LiF}+\mathrm{HCl}\left(48 \mathrm{~h}, 50^{\circ} \mathrm{C}\right) \\
\mathrm{NH}_{4} \mathrm{~F} / \mathrm{KF}+\mathrm{HCl}\left(48 \mathrm{~h}, 40^{\circ} \mathrm{C}\right) \\
\mathrm{NaF}+\mathrm{HCl}\left(24 \mathrm{~h}, 60^{\circ} \mathrm{C}\right)\end{array}$ & $\begin{array}{l}- \\
- \\
\text { DMSO }(24 \mathrm{~h}), \mathrm{NH}_{3} \cdot \mathrm{H}_{2} \mathrm{O}(2 \mathrm{~h}) \text { or urea } \\
\quad\left(24 \mathrm{~h}, 60^{\circ} \mathrm{C}\right)\end{array}$ & \\
\hline $\mathrm{Ti}_{3} \mathrm{AlC}_{2}$ & $\mathrm{NH}_{4} \mathrm{HF}_{2}(10-160 \mathrm{~min}, \mathrm{RT})$ & - & {$[25]$} \\
\hline $\mathrm{Ti}_{3} \mathrm{AlC}_{2}$ & $\mathrm{NaOH}\left(12 \mathrm{~h}, 270^{\circ} \mathrm{C}\right)$ & - & [27] \\
\hline $\mathrm{Ti}_{4} \mathrm{AIN}_{3}$ & $\begin{array}{l}\text { Mixture of LiF, KF, NaF } \\
\left(30 \mathrm{~min}, 550^{\circ} \mathrm{C}\right)\end{array}$ & TBAOH (5 min) & [28] \\
\hline $\mathrm{Ti}_{3} \mathrm{AlC}_{2}$ & - & DMSO $(18 h, R T)$ & [31] \\
\hline $\mathrm{Nb}_{2} \mathrm{AlC}$ & $50 \% \mathrm{HF}\left(48 \mathrm{~h}, 55^{\circ} \mathrm{C}\right)$ & Isopropylamine (18 h, RT) & [32] \\
\hline $\begin{array}{l}\mathrm{V}_{2} \mathrm{AIC} \\
\mathrm{Ti}_{3} \mathrm{AICN}\end{array}$ & $\begin{array}{l}48 \% \mathrm{HF}(92 \mathrm{~h}, \mathrm{RT}) \\
30 \% \mathrm{HF}(18 \mathrm{~h}, \mathrm{RT})\end{array}$ & TBAOH (4 h, RT) & [33] \\
\hline $\mathrm{Ti}_{3} \mathrm{AlC}_{2}$ & 40\% HF (3 days, RT) & TPAOH (3 days, RT) & {$[34]$} \\
\hline
\end{tabular}

method successfully generated other MAX phases such as $\mathrm{Nb}_{2} \mathrm{AlC}$ and $\mathrm{Ti}_{2} \mathrm{AlC}$, proving that this method is versatile to multiple MAX phases. $\mathrm{Ti}_{3} \mathrm{C}_{2}$ and $\mathrm{Ti}_{2} \mathrm{C}$ nanosheets can also be generated through etching of various fluoride salts such as lithium fluoride (LiF), sodium fluoride $(\mathrm{NaF})$, potassium fluoride $(\mathrm{KF})$ and ammonium fluoride $\left(\mathrm{NH}_{4} \mathrm{~F}\right)$ in $\mathrm{HCl}$ with optimum temperature, resulting in MXene that can store methane at atmospheric pressure and absorb methane under high pressure [24]. Another study was done where $\mathrm{Ti}_{3} \mathrm{AlC}_{2}$ films were etched using only ammonium bifluoride $\left(\mathrm{NH}_{4} \mathrm{HF}_{2}\right)$, without using any harsh acid [25]. They found that during the etching process, the MXene layers were simultaneously intercalated with the ammonium species $\left(\mathrm{NH}_{4}^{+}\right)$, producing layers with larger lattice parameter ( $>25 \%$ ) compared to HF-etched $\mathrm{Ti}_{3} \mathrm{C}_{2}$.

Although many studies still employ HF/fluoride source as the preferred MAX phase etchant, this acid is very toxic and is very dangerous to handle, especially for biological applications, because even a tiny amount of unreacted HF could induce cell death [14]. In humans, HF can cause systemic toxicity that can lead to fatality [26]. Therefore, direct use of HF, or even in situ formation of HF poses safety and environmental hazards that hinders the advancement of MXenes' application [26]. Another downside of this type of etching is the abundance of fluoride ions $\left(\mathrm{F}^{-}\right)$on the surface of MXene, which decrease the amount of other functional groups $(-\mathrm{OH},-\mathrm{O}),-\mathrm{OH}$ and $-\mathrm{O}$ functional groups are easier to be functionalized, and it is challenging to conjugate F- ions [14]. Hence, a fluorine-free etching method is more favourable to produce MXenes with controllable functional surface termination for various biomedical applications. One study by Li et al. proposed and successfully fabricated multilayer $\mathrm{Ti}_{3} \mathrm{C}_{2} \mathrm{~T}_{\mathrm{x}}$ through alkali-assisted hydrothermal method using aqueous sodium hydroxide $(\mathrm{NaOH})$ solution as the etchant, at a high temperature of $270{ }^{\circ} \mathrm{C}$ [27]. Via this method, they reported production of highquality $\mathrm{Ti}_{3} \mathrm{C}_{2}$ powder with $92 \%$ purity with more $-\mathrm{OH}$ and $-\mathrm{O}$ terminations. Another 
method involves the use of molten salt, by mixing of $\mathrm{Ti}_{4} \mathrm{AlN}_{3}$ powder with molten fluoride salt (mixture of $\mathrm{LiF}, \mathrm{KF}$, and $\mathrm{NaF}$ of a specific ratio) at $550{ }^{\circ} \mathrm{C}$ for $30 \mathrm{~min}$ [28]. After delamination of the $\mathrm{Ti}_{4} \mathrm{~N}_{3}$ layers with tetrabutylammonium hydroxide ( $\mathrm{TBAOH}$ ), multilayered and single-layered MXenes were produced.

After etching, MXenes typically undergo delamination process to separate the MXene sheets so that the properties of MXenes' 2D state can be investigated further [29]. The delamination step can be done by using intercalating agent/intercalant and sonication, where absence of intercalating agents yield smaller sized MXenes with larger defects $[13,29,30]$. Intercalating agents often increase the $c$-lattice parameter, or the distance between two consecutive MXene sheets, making them easier to separate/delaminate to form pure MXene sheets [29]. Examples of common intercalants used include dimethylsulfoxide (DMSO) and isopropylamine, which are polar organic solvents [31, 32] (Table 1). The delamination of $\mathrm{Ti}_{3} \mathrm{C}_{2}$ sheets using DMSO for $24 \mathrm{~h}$ at room temperature, resulted in increase of $c$-lattice parameter from $19.5 \pm 0.1 \AA$ to $35.04 \pm 0.02 \AA$, indicating that the MXene sheets were successfully intercalated with DMSO [31]. The delamination of $\mathrm{Nb}_{2} \mathrm{C}$ (niobium carbide) MXenes for lithium energy storage devices were produced from isopropylamine as the intercalant for $18 \mathrm{~h}$ at room temperature, and the interlayer distance increased by $\approx 12.3 \AA$ [32]. Other intercalants agents such as tetrabutylammonium hydroxide (TBAOH) or tetrapropylammonium hydroxide (TPAOH) were also reported [33]. The used of TBAOH for delamination of vanadium carbide $\left(\mathrm{V}_{2} \mathrm{CT}_{\mathrm{x}}\right)$ and titanium carbonitride $\left(\mathrm{Ti}_{3} \mathrm{CNT}_{\mathrm{x}}\right)$ induced huge impromptu swelling, and simultaneously weakened the interlayer interactions, therefore increasing the yields of delaminated MXene compared to using DMSO [33]. Ultrathin $\mathrm{Ti}_{3} \mathrm{C}_{2}(5-6 \mathrm{~nm})$ was synthesised using a modified chemical exfoliation, by HF etching for 30 days followed by intercalation with TPAOH for another 3 days [34]. The average lateral size of the thin $\mathrm{Ti}_{3} \mathrm{C}_{2}$ flakes was around $150 \mathrm{~nm}$, and the flakes also exhibited 2D sheet-like morphology upon intercalation with TPAOH.

It is crucial for the MXene nanosheets to be nano in size for biological applications. Traditional multi-layered MXenes, synthesised from top-down approach, produce large sheet sizes, that may lead to potential biosafety issues, and low therapeutic outcome. Also, large MXene sheets are not suitable for intravenous (IV) administration, because this usually requires nano-sized particles for easy transport in our circulatory system and good penetration and accumulation in cancer tissues [35]. Hence, based on the overall studies reported on top-down synthesis of MXene, the optimization of etchant, etching time, and type of intercalant are key parameters to ensure successful synthesis of biocompatible MXene nanosheets.

\section{Bottom-up approach}

Another lesser known MXene synthesis technique is the bottom-up synthesis approach, by atomic scale control [13]. Bottom-up synthesis commonly begins from small organic/inorganic molecules/atoms, followed by crystal growth that can be organized to form 2D-ordered layer [14]. The most common method for this approach is the chemical vapour deposition (CVD) technique, which can produce good quality of thin films on various substrates (Fig. 5a). In general, CVD produces very thin films that are often multi-layered (at least six layers) [36]. The first MXene 


\section{a Chemical vapor deposition}

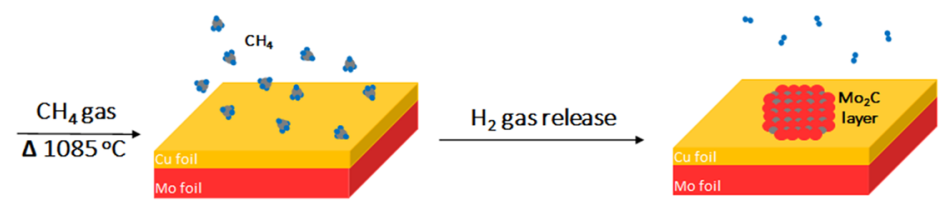

\section{b Salt template synthesis}

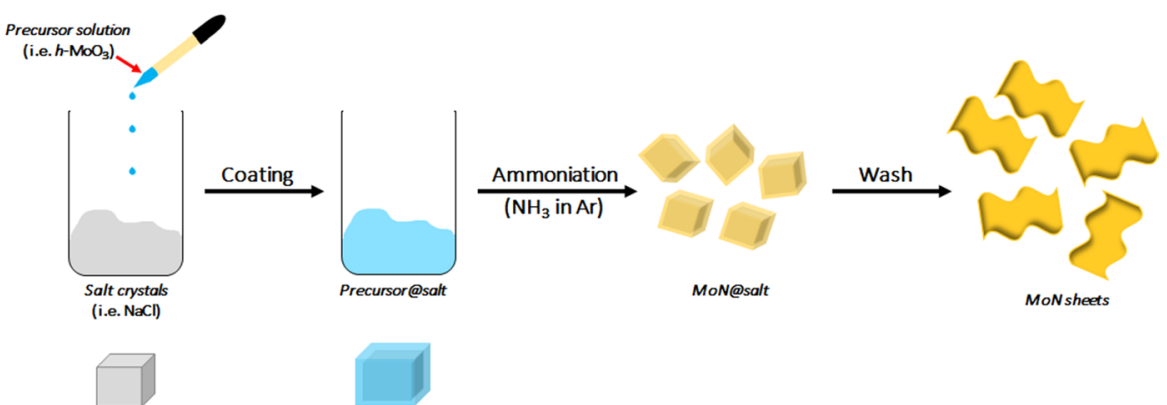

Fig. 5 Schematic illustration of bottom-up methods. a Chemical vapour deposition of Mo and $C$ to form $\mathrm{MO}_{2} \mathrm{C}$ thin film in gas chamber based on the report in [37], $\mathbf{b}$ Salt-template synthesis of MoN nanosheets. Readapted with permission from [38]. Copyright (2017) American Chemical Society

synthesis by CVD technique produced high-quality ultrathin $\mathrm{Mo}_{2} \mathrm{C}$ (molybdenum carbide) using methane gas $\left(\mathrm{CH}_{4}\right)$ as the carbon source and a $\mathrm{Cu} / \mathrm{Mo}$ (copper/molybdenum) foil as the substrate at temperature above $1085{ }^{\circ} \mathrm{C}$ (Fig. 5a). The optimisation of growth temperature and growth time produced range of films with lateral sizes between 10 and $100 \mu \mathrm{m}$. The $\mathrm{Mo}_{2} \mathrm{C}$ films synthesized were defect-free and possessed high crystallinity, which may indicate the lack of surface functional groups [37]. This is unfortunately not ideal for biomedical applications, as well-functionalized MXenes are preferred for the surface engineering of the nanosheets, and the size $(\mu \mathrm{m})$ is too large for permeation of cells. Other than CVD, methods such as template method and plasma-enhanced pulsed laser deposition (PELPD) had also been explored for MXene synthesis $[38,39]$. The first PELPD-synthesized ultrathin $\mathrm{Mo}_{2} \mathrm{C}$ films using methane plasma as a carbon source, reacted with Mo vapour which was generated by the pulsed laser. This reaction was done on a sapphire substrate, heated to $700{ }^{\circ} \mathrm{C}$ to produce high-quality films with film thickness that can be controlled by varying the laser pulse rate. Other modification such as the scalable salt-template synthesis of $2 \mathrm{D}$ nitrides $\left(\mathrm{MoN}, \mathrm{V}_{2} \mathrm{~N}\right.$ and $\left.\mathrm{W}_{2} \mathrm{~N}\right)$ by reducing their respective $2 \mathrm{D}$ hexagonal oxides with ammonia was reported [35]. They found that salt-templating is capable of producing 2D metal oxide precursors, and the MoN nanosheets produced from this synthesis were hydrophilic and had sub-nm thickness when dispersed in water (Fig. 5b) [38]. This method is proven to be applicable on other metal oxides, such as $\mathrm{V}_{2} \mathrm{~N}$ and $\mathrm{W}_{2} \mathrm{~N}$ nanosheets. Nevertheless, only limited information of bottom-up synthesis of biocompatible MXene are available, provide room for improvement [29]. Another important aspect of both top-down and bottom-up syntheses is the robustness and safe methods for large-scale synthesis, which also needs to be further investigated. 
Table 3 Comparison of top-down and bottom-up synthesis approaches of MXene

\begin{tabular}{|c|c|c|c|}
\hline & Top-down approach & Bottom-up approach & Refs. \\
\hline Precursor & Initiate from MAX phase of 3D structure & $\begin{array}{l}\text { Initiate from atom to crystal growth of } \\
\text { MXene film }\end{array}$ & {$[10,36]$} \\
\hline Method & $\begin{array}{l}\text { Involves with chemical etchants such } \\
\text { as HF acid }\end{array}$ & $\begin{array}{l}\text { Apply chemical vapour deposition or } \\
\text { salt-templating method or plasma- } \\
\text { enhanced deposition }\end{array}$ & [36-38] \\
\hline Synthesis condition & Pressure-less synthesis & Control gas flow as carbon source & {$[10,37]$} \\
\hline Temperature & $\begin{array}{l}\text { Require room or low temperature for } \\
\text { synthesis }\end{array}$ & $\begin{array}{l}\text { Require high temperature of } \sim 1000^{\circ} \mathrm{C} \\
\text { for synthesis }\end{array}$ & {$[36]$} \\
\hline Morphology & $\begin{array}{l}\text { Large irregular MXene sheet could be } \\
\text { produced with a lateral size of a few } \\
\text { hundred nanometers and thin sheets } \\
\text { with a thickness between } 10 \text { and } \\
200 \mathrm{~nm}\end{array}$ & $\begin{array}{l}\text { Produce defect-free and highly crystal- } \\
\text { line thin film of multilayers with a } \\
\text { lateral size of between } 10 \text { and } 100 \mu \mathrm{m}\end{array}$ & {$[22,36]$} \\
\hline Surface properties & $\begin{array}{l}\text { Functionalized -OH and -O after } \\
\text { synthesis }\end{array}$ & $\begin{array}{l}\text { Lack of functional groups after syn- } \\
\text { thesis }\end{array}$ & {$[3,37]$} \\
\hline
\end{tabular}

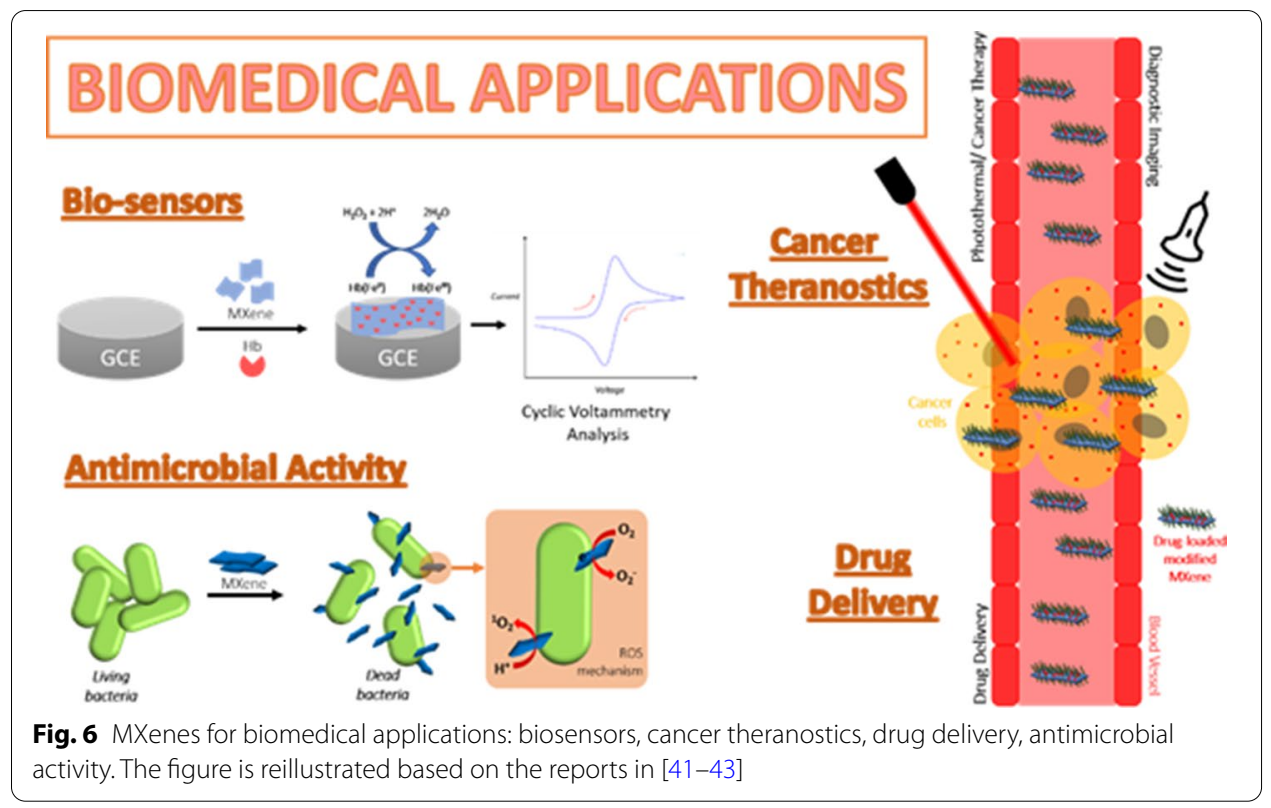

The main differences between the top-down and bottom-up synthesis approaches of MXene and the material properties discussed are as summarized in Table 3.

\section{Biomedical applications of MXene}

MXenes exist as stacked 2D sheets, held together by weak van der Waals (vdW) forces and/or strong hydrogen-bonding interactions between the surface functional groups [40]. These surface functional groups are chemically reactive and can be further functionalized. In biomedical research studies, the surfaces of MXenes can be tuned with various materials 
Table 4 Summary of types of MXenes, their syntheses methods, surface functionalization and biomedical applications. Note: LOD indicates the lowest level of detection within the detection range stated. LOD is the lowest concentration of a substance/analyte that can be detected by a reliable analytical method, whereas the detection range includes lowest to highest concentrations of substance that are able to be detected accurately and precisely

\begin{tabular}{|c|c|c|c|c|c|}
\hline $\begin{array}{l}\text { Type of } \\
\text { MXene/MXene } \\
\text { composite }\end{array}$ & $\begin{array}{l}\text { Synthesis method } \\
\text { of MXene }\end{array}$ & Functionalization(s) & Application & Application details & Ref \\
\hline $\mathrm{TiO}_{2}-\mathrm{Ti}_{3} \mathrm{C}_{2}$ & $\begin{array}{l}\text { Hydrothermal } \\
\text { synthesis }\end{array}$ & $\begin{array}{l}\text { Hemoglobin }(\mathrm{Hb}) \text {, } \\
\text { Nafion }\end{array}$ & Bio-sensor & $\begin{array}{l}\text { Detection of } \\
\text { hydrogen } \\
\text { peroxide (LOD: } \\
\mathbf{1 4} \mathrm{nM} \text {; range: } \\
\mathbf{0 . 1}-\mathbf{3 8 0} \boldsymbol{\mu M} \text { ) } \\
\text { and nitrite (LOD: } \\
\mathbf{0 . 1 2} \boldsymbol{\mu M} \text {; range: } \\
\mathbf{0 . 1}-\mathbf{3 8 0} \boldsymbol{\mu M} \text { ) via } \\
\text { amperometry } \\
\text { changes }\end{array}$ & {$[44,45]$} \\
\hline $\mathrm{Au} / \mathrm{Ti}_{3} \mathrm{C}_{2}$ & HF etching & $\begin{array}{l}\text { Glucose oxidase } \\
\left(\mathrm{GO}_{x}\right)\end{array}$ & & 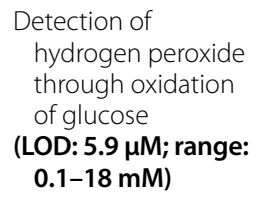 & {$[46]$} \\
\hline $\mathrm{Ti}_{3} \mathrm{C}_{2}$ & $\mathrm{LiF}+\mathrm{HCl}$ etching & $\begin{array}{l}\text { Poly-L-lysine (PLL), } \\
\mathrm{GO}_{x}\end{array}$ & & $\begin{array}{l}\text { Detection of } \\
\text { hydrogen peroxide } \\
\text { through oxidation } \\
\text { of glucose } \\
\text { (LOD: } 2.6 \mu \mathrm{M} \text {; } \\
\text { range: } \mathbf{4 - 2 0} \boldsymbol{\mu M} \text {, } \\
\mathbf{0 . 0 2 - 1 . 1} \mathrm{mM} \text { ) }\end{array}$ & {$[47]$} \\
\hline $\mathrm{Ti}_{3} \mathrm{C}_{2}$ & HF etching & Tyrosinase, chitosan & & $\begin{array}{l}\text { Detection of phenol } \\
\text { in real water } \\
\text { samples } \\
\text { (LOD: } \mathbf{1 2} \mathbf{~ n M ; ~ r a n g e : ~} \\
\mathbf{0 . 0 5 - 1 5 . 5 \mu M )}\end{array}$ & [48] \\
\hline $\mathrm{Ti}_{3} \mathrm{C}_{2}$ & HF etching & $\begin{array}{l}\beta \text {-hydroxybutarate } \\
\text { dehydrogenase, } \\
\text { bovine serum } \\
\text { albumin (BSA), } \\
\text { glutarate }\end{array}$ & & $\begin{array}{l}\text { Detection of } \\
\beta \text {-hydroxybutarate } \\
\text { (LOD: } 44.5 \mu \mathrm{M} ; \\
\text { range: } 360 \mu \mathrm{M}- \\
17.91 \mathrm{mM} \text { ) }\end{array}$ & {$[49]$} \\
\hline $\mathrm{Ti}_{3} \mathrm{C}_{2}$ & $\mathrm{LiF}+\mathrm{HCl}$ etching & $\begin{array}{l}\text { (3-Aminopropyl) } \\
\text { triethoxysilane } \\
\text { (APTES), BSA, } \\
\text { anti-CEA }\end{array}$ & & $\begin{array}{l}\text { Detection of } \\
\text { carcinoembryonic } \\
\text { antigen (CEA) } \\
\text { (LOD: } \mathbf{1 . 8 \times 1 0 ^ { - }} \\
{ }^{\mathbf{5}} \mathbf{\mathbf { ~ m L }} \mathbf{- 1} ; \\
\text { range: } \mathbf{0 . 0 0 0 1 -} \\
\mathbf{2 0 0 0} \mathbf{n g ~ m L}^{-1} \text { ) }\end{array}$ & {$[50]$} \\
\hline $\mathrm{Ti}_{3} \mathrm{C}_{2}$ & $\begin{array}{l}\text { HF etching, } \\
\text { TMAOH interca- } \\
\text { lation }\end{array}$ & $\begin{array}{l}\text { AuNPs, staphylo- } \\
\text { coccal protein A, } \\
\text { anti-CEA }\end{array}$ & & $\begin{array}{l}\text { Detection of CEA via } \\
\text { surface plasmon } \\
\text { resonance (SPR) } \\
\text { (LOD: } \mathbf{0 . 7} \mathbf{f M ;} \\
\text { range: } \mathbf{0 . 0 0 0 2 - 2 0} \\
\mathbf{0 0 0} \mathbf{~ p M )}\end{array}$ & {$[51]$} \\
\hline $\mathrm{Ti}_{3} \mathrm{C}_{2}$ & HF etching & $\begin{array}{l}\text { Hollow AuNPs, } \\
\text { APTES, SPA, anti- } \\
\text { CEA }\end{array}$ & & 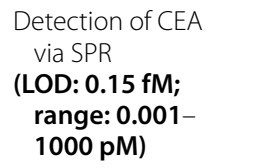 & {$[52]$} \\
\hline $\mathrm{Ti}_{3} \mathrm{C}_{2}$ & $\begin{array}{l}\text { HF etching, DMSO } \\
\text { intercalation }\end{array}$ & $\begin{array}{l}\text { Osteopontin (OPN) } \\
\text { aptamer, phos- } \\
\text { phomolybdic acid } \\
\left(\mathrm{PMO} \mathrm{O}_{12}\right) \text {, polypyr- } \\
\text { role }(\mathrm{PPy}),\end{array}$ & & $\begin{array}{l}\text { Detection of overex- } \\
\text { pressed OPN } \\
\text { (LOD: } 0.98 \mathrm{fg} \mathrm{mL}^{-1} \text {; } \\
\text { range: } \\
\mathbf{0 . 0 0 5} \mathrm{pg} \mathrm{mL}^{-1} \mathbf{~}_{-} \\
\mathbf{1 0} \mathrm{ng} \mathrm{mL}^{-1} \text { ) }\end{array}$ & {$[53]$} \\
\hline
\end{tabular}


Table 4 (continued)

\begin{tabular}{|c|c|c|c|c|c|}
\hline $\begin{array}{l}\text { Type of } \\
\text { MXene/MXene } \\
\text { composite }\end{array}$ & $\begin{array}{l}\text { Synthesis method } \\
\text { of MXene }\end{array}$ & Functionalization(s) & Application & Application details & Ref \\
\hline $\mathrm{Ta}_{4} \mathrm{C}_{3}$ & HF etching & $\begin{array}{l}\text { Manganese oxide } \\
\left(\mathrm{MnO}_{\mathrm{x}}\right) \text {, soybean } \\
\text { phospholipid (SP) }\end{array}$ & $\begin{array}{l}\text { Cancer theranos- } \\
\text { tics }\end{array}$ & $\begin{array}{l}\text { Multi-imaging- } \\
\text { guided (MRI, CT } \\
\text { scan and PAI) PTT }\end{array}$ & {$[54]$} \\
\hline $\mathrm{Ti}_{3} \mathrm{C}_{2}$ & $\begin{array}{l}\text { HF etching, TPAOH } \\
\text { intercalation }\end{array}$ & $\begin{array}{l}\text { Manganese oxide } \\
\left(\mathrm{MnO}_{\mathrm{x}}\right) \text {, soybean } \\
\text { phospholipid (SP) }\end{array}$ & & MRI-guided PTT & {$[55]$} \\
\hline $\mathrm{Ta}_{4} \mathrm{C}_{3}$ & HF etching & $\begin{array}{l}\text { Supermagnetic iron } \\
\text { oxide nanoparti- } \\
\text { cles (IONPs) }\end{array}$ & & MRI-guided PTT & {$[56]$} \\
\hline $\mathrm{Ti}_{3} \mathrm{C}_{2}$ & $\begin{array}{l}\text { HF etching, TPAOH } \\
\text { intercalation }\end{array}$ & $\begin{array}{l}\text { Poly(lactic-co-gly- } \\
\text { colic acid) (PLGA), } \\
\text { SP, IONPs }\end{array}$ & & MRI-guided PTT & [34] \\
\hline $\mathrm{Nb}_{2} \mathrm{C}$ & $\begin{array}{l}\text { HF etching, TPAOH } \\
\text { intercalation }\end{array}$ & $\begin{array}{l}\text { Polyvinylpyrrolidone } \\
\text { (PVP) }\end{array}$ & & PAl-guided PTT & [57] \\
\hline $\mathrm{Nb}_{2} \mathrm{C}$ & $\begin{array}{l}\text { HF etching, TPAOH } \\
\text { intercalation }\end{array}$ & $\begin{array}{l}\text { Cetanecyltrimeth- } \\
\text { ylammonium } \\
\text { chloride (CTAC), } \\
\text { APTES, polyethyl- } \\
\text { ene glycol (PEG) }\end{array}$ & & PAI-guided PTT & {$[58]$} \\
\hline $\mathrm{Ti}_{3} \mathrm{C}_{2}$ QDs & $\begin{array}{l}\text { Hydrothermal } \\
\text { synthesis }\end{array}$ & - & & $\begin{array}{l}\text { Multicolour cellular } \\
\text { imaging }\end{array}$ & [59] \\
\hline $\mathrm{Ti}_{3} \mathrm{C}_{2}$ QDs & $\begin{array}{l}\text { Sonication prob- } \\
\text { ing in TPAOH }\end{array}$ & - & & $\begin{array}{l}\text { PTT in NIR biowin- } \\
\text { dow, biocompat- } \\
\text { ibility test }\end{array}$ & [60] \\
\hline $\mathrm{Ti}_{2} \mathrm{~N}$ QDs & $\begin{array}{l}\mathrm{KF}+\mathrm{HCl} \text { etching, } \\
\text { sonication in } \\
\text { NMP }\end{array}$ & SP & & PAl-guided PTT & [61] \\
\hline $\mathrm{Nb}_{2} \mathrm{C}$ QDs & $\begin{array}{l}\text { HF etching, TPAOH } \\
\text { sonication } \\
\text { (ultrasound- } \\
\text { assisted) }\end{array}$ & - & & $\begin{array}{l}\text { Fluorescence imag- } \\
\text { ing, metal ions } \\
\text { sensing }\end{array}$ & [62] \\
\hline $\mathrm{Ti}_{3} \mathrm{C}_{2}$ & $\begin{array}{l}\text { HF etching, TPAOH } \\
\text { intercalation }\end{array}$ & $\begin{array}{l}\text { SP, doxorubicin } \\
\text { (Dox) }\end{array}$ & Drug delivery & $\begin{array}{l}\text { Chemotherapeutic } \\
\text { agent, synergistic } \\
\text { chemotherapy and } \\
\text { PTT }\end{array}$ & [63] \\
\hline $\mathrm{Ti}_{3} \mathrm{C}_{2}$ & HF etching & Cellulose, Dox & & $\begin{array}{l}\text { Chemotherapeutic } \\
\text { agent, synergistic } \\
\text { chemotherapy and } \\
\text { PTT }\end{array}$ & [64] \\
\hline $\mathrm{Ti}_{3} \mathrm{C}_{2}$ & HF etching & $\begin{array}{l}\text { Polyacrylamide } \\
\text { (PAM) }\end{array}$ & & Study of drug release & {$[65]$} \\
\hline $\mathrm{Ti}_{3} \mathrm{C}_{2}$ & $\mathrm{LiF}+\mathrm{HCl}$ etching & $\begin{array}{l}\text { Cobalt nanowires } \\
\text { (CoNWs), Dox }\end{array}$ & & $\begin{array}{l}\text { Study of drug release } \\
\text { control, synergistic } \\
\text { chemotherapy and } \\
\text { PTT }\end{array}$ & [66] \\
\hline $\mathrm{Ti}_{3} \mathrm{C}_{2}$ & $\mathrm{LiF}+\mathrm{HCl}$ etching & - & $\begin{array}{l}\text { Antimicrobial } \\
\text { activity }\end{array}$ & $\begin{array}{l}\text { Study of antibacterial } \\
\text { activity }\end{array}$ & [67] \\
\hline $\mathrm{Ti}_{3} \mathrm{C}_{2}$ & $\mathrm{LiF}+\mathrm{HCl}$ etching & PVDF & & $\begin{array}{l}\text { For wastewater treat- } \\
\text { ment }\end{array}$ & [68] \\
\hline $\mathrm{Ti}_{3} \mathrm{C}_{2}$ & $\mathrm{LiF}+\mathrm{HCl}$ etching & $\begin{array}{l}\text { Chitosan, glutaral- } \\
\text { dehyde }\end{array}$ & & $\begin{array}{l}\text { Study of antibacterial } \\
\text { activity }\end{array}$ & [69] \\
\hline $\mathrm{Ti}_{3} \mathrm{C}_{2}, \mathrm{Ti}_{2} \mathrm{C}$ & HF etching & - & & $\begin{array}{l}\text { Comparison study } \\
\text { of antibacterial } \\
\text { activity }\end{array}$ & [70] \\
\hline $\mathrm{Ti}_{3} \mathrm{C}_{2}$ & HF etching & PLL & & $\begin{array}{l}\text { Study of antibacterial } \\
\text { activity }\end{array}$ & {$[22]$} \\
\hline
\end{tabular}


Table 4 (continued)

\begin{tabular}{|c|c|c|c|c|c|}
\hline $\begin{array}{l}\text { Type of } \\
\text { MXene/MXene } \\
\text { composite }\end{array}$ & $\begin{array}{l}\text { Synthesis method } \\
\text { of MXene }\end{array}$ & Functionalization(s) & Application & Application details & Ref \\
\hline $\mathrm{Ti}_{3} \mathrm{C}_{2}$ & $\mathrm{LiF}+\mathrm{HCl}$ etching & - & & $\begin{array}{l}\text { Study of antibacterial } \\
\text { activity }\end{array}$ & [71] \\
\hline $\mathrm{Ti}_{3} \mathrm{C}_{2}$ & HF etching & - & & $\begin{array}{l}\text { Study of antifungal } \\
\text { activity }\end{array}$ & [20] \\
\hline
\end{tabular}

suitable for biosensors, cancer theranostics (therapeutics and diagnostics), drug delivery, and antimicrobial activity (Fig. 6). The type of MXene composite and its application in biomedical are summarized in Table 4.

\section{Biosensors}

\section{Enzyme-based biosensors}

MXenes are well known for its high electrical conductivity $\left(\mathrm{Ti}_{3} \mathrm{C}_{2} \mathrm{~T}_{\mathrm{x}}\right.$ monolayer: $4600 \pm 1100 \mathrm{~S} / \mathrm{cm}$ ) [72], excellent ion transport behaviour, good biocompatibility, high surface area to volume ratio and easy to functionalize [73]. Hence, these properties allow MXenes to be recognized as a very advanced biosensing tool which can detect various small molecules, large biomolecules, and even cancer cells. Generally, for detection of small molecules, enzymes are immobilized on the MXene nanosheets to catalyse the chemical reaction of the molecules. An organ-like $\mathrm{TiO}_{2}-\mathrm{Ti}_{3} \mathrm{C}_{2}$ nanocomposite was synthesised via hydrothermal synthesis, and was fabricated with hemoglobin $(\mathrm{Hb})$ to create a mediator-free biosensor that can detect hydrogen peroxide $\left(\mathrm{H}_{2} \mathrm{O}_{2}\right)$ [44]. $\mathrm{H}_{2} \mathrm{O}_{2}$ is a reactive oxygen species (ROS) that is generated from aerobic metabolism, which regulates various biological processes at physiological amounts but very toxic at large amounts in the body [74]. MXenes are capable of $\mathrm{H}_{2} \mathrm{O}_{2}$ sensing, through the oxidation of their surface terminations by $\mathrm{H}_{2} \mathrm{O}_{2}$, and this reaction will increase the oxygen density on their surface and promote the charge transfer process [14]. The benefit of employing $\mathrm{TiO}_{2}-\mathrm{Ti}_{3} \mathrm{C}_{2}$ nanocomposite, or nanomaterials in general, is to facilitate the direct electron transfer (DET) while retaining the bioactivity of the immobilized enzymes [75]. The $\mathrm{TiO}_{2}-\mathrm{Ti}_{3} \mathrm{C}_{2}$ nanocomposite is a biocompatible matrix suitable for enzyme immobilization, with their biosensors having a low limit of detection (LOD) and wide linear range for $\mathrm{H}_{2} \mathrm{O}_{2}$ detection [44]. Moreover, the same system could be applied for the detection of nitrite $\left(\mathrm{NO}_{2}{ }^{-}\right)$with and even lower LOD and wider detection range [45].

MXenes have been fabricated for amperometric biosensor platform, based on $\mathrm{Au} /$ $\mathrm{Ti}_{3} \mathrm{C}_{2}$ nanocomposite for sensitive enzymatic glucose detection [46]. The glucose biosensor works by immobilizing glucose oxidase $\left(\mathrm{GO}_{\mathrm{x}}\right)$ to an appropriate electrochemical transducer, and further functionalized with gold $(\mathrm{Au})$. The $\mathrm{GO}_{\mathrm{x}}$ catalyses the oxidation of glucose to gluconolactone and $\mathrm{H}_{2} \mathrm{O}_{2}$, while the $\mathrm{Au}$ improves electron transfer process between the $\mathrm{GO}_{\mathrm{x}}$ and Au-coated glassy carbon electrode (GCE). The $\mathrm{Au} / \mathrm{Ti}_{3} \mathrm{C}_{2}$ nanocomposite biosensor yielded low LOD with wide linear range for glucose detection, with excellent stability and reproducibility. Modification of the $\mathrm{Au} / \mathrm{Ti}_{3} \mathrm{C}_{2}$ nanocomposite with poly-L-lysine (PLL) increased the loading capacity by $39.5 \mathrm{wt} \%$ at $\mathrm{pH} 6.7$, and by 31.7 wt\% at $\mathrm{pH} 5.5$ [47]. As the $\mathrm{pH}$ decreases, the charge density of PLL increase, providing 
a stronger electrostatic attraction between PLL and $\mathrm{Ti}_{3} \mathrm{C}_{2}$ nanosheets and $\mathrm{GO}_{\mathrm{x}}$ molecules. The PLL-modified $\mathrm{Au} / \mathrm{Ti}_{3} \mathrm{C}_{2}$ biosensor had a lower LOD and could detect glucose in both micro- and milli-Molar ranges [46]. $\mathrm{A} \mathrm{Ti}_{3} \mathrm{C}_{2}$-based tyrosinase (Tyr) biosensor was fabricated for detection of phenol in real water samples [48]. Phenolic compounds are abundant in nature, and they tend to dissociate into other moieties that are very toxic upon entry in water [76]. Chitosan (Chi) was added to the biosensor to hinder direct electron transfer from the electrode itself. The tyrosinase biosensor was reported to have an ultra-low LOD in the nano-Molar scale, with high detection sensitivity of $414 \mathrm{~mA} \mathrm{M}^{-1}$.

Modification of $\mathrm{Ti}_{3} \mathrm{C}_{2}$ nanosheets with $\beta$-hydroxyburate dehydrogenase enable the detection of $\beta$-hydroxyburate ( $\beta$-HBA) [49]. Determination of $\beta$-HBA is important for humans, especially for patients with diabetic ketosis as the metabolic acidosis can occur when blood $\beta$-HBA levels reach up to $20 \mathrm{mM}$ [77]. The $\mathrm{Ti}_{3} \mathrm{C}_{2}$-based $\beta$-HBA biosensor was fabricated using gold-printed circuit board (Au-PCB) as the electrode instead of the conventional GCE, and the overall performance of the biosensor was excellent, with low LOD and very wide detection range [49].

\section{Detection of cancer biomarkers}

Carcinoembryonic antigen (CEA) is generally used as tumor markers [51]. The first MXene-based CEA detector use single/few-layered $\mathrm{Ti}_{3} \mathrm{C}_{2}$ MXene coated with an amino groups of receptor (in this case 3-Aminopropyl triethoxysilane (APTES)) to covalently immobilize carcinoembryonic monoclonal antibody for cancer biomarker detection [50]. Glassy carbon electrode (GCE) was employed as the electrode, and BSA was used to block unspecified active site of the bioelectrode to complete the biosensing platform, resulting in an extremely low LOD and very wide linear detection range in the nanoscale with sensitivity of $37.9 \mu \mathrm{A} \mathrm{ng}^{-1} \mathrm{~mL} \mathrm{~cm}^{-2}$ per decade. To enhance the sensitivity of CEA biosensor, surface plasmon resonance (SPR) technology has been introduced, which enables the measurement of refractive-index and real-time interactions of biological and chemical molecules [52]. In this study, prepared $\mathrm{Ti}_{3} \mathrm{C}_{2}$ nanosheets were functionalized with AuNPs (gold nanoparticles) through a chemical reduction method [52]. The synthesized nanocomposite was further decorated with staphylococcal protein A (SPA) to immobilize the anti-CEA antibody $\left(\mathrm{Ab}_{1}\right)$ onto the nanocomposite surface (labelled as $\mathrm{Ti}_{3} \mathrm{C}_{2}$ MXene/AuNPs/SPA). Another nanocomposite MWPAg- $\mathrm{A}_{2}$ synthesized from multi-walled carbon nanotubes-polydopamine-silver nanoparticles (MWCNTs-PDAAgNPs) nanohybrids that conjugated with polyclonal anti-CEA antibodies $\left(\mathrm{Ab}_{2}\right)$ to enhance the signal of the sensing system, which enables ultra-low LOD in the femtoscale and detection range in the pico-scale [51]. Ultrathin $\mathrm{Ti}_{3} \mathrm{C}_{2}$ was also employed on the sensing platform and signal enhancer of the SPR biosensor, which also exhibited an ultra-low LOD and wide detection range in pico-scale [78].

Apart from detecting CEA as tumour marker, overexpressed proteins such as osteopontin (OPN), which could lead to cancer progression have also been reported. OPN is a phosphoprotein that regulates tumour metastasis, and is commonly overexpressed in tumour stromal cells that may lead to progression of cancer [79]. $\mathrm{Ti}_{3} \mathrm{C}_{2} \mathrm{~T}_{\mathrm{X}}-\mathrm{PMo}_{12}$ (phosphomolybdic acid) nanohybrid was embedded with polypyrrole (PPy), as a platform to boost the anchoring of osteopontin (OPN) aptamer for OPN detection [53]. 
The PPy@ $\mathrm{Ti}_{3} \mathrm{C}_{2} \mathrm{~T}_{\mathrm{X}} / \mathrm{PMo}_{12}$-based aptasensor consisted of $\mathrm{Ti}^{4+}$ and $\mathrm{Mo}^{4+}$ ions which were integrated within the MXene nanosheets and conjugated PPy matrix to facilitate the immobilization of the targeted OPN aptamer strands. This proposed aptasensor displayed ultra-low LOD in femto-scale, with a very wide linear concentration range of

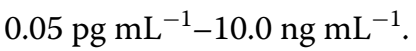

Based on both enzyme-based and cancer biomarkers biosensors studies, MXenes, especially $\mathrm{Ti}_{3} \mathrm{C}_{2} \mathrm{~T}_{\mathrm{X}}$, can immobilize various types of molecules for improved stability and performance of the biosensors. MXene composite is an advance biocompatible matrix suitable for mediator-free, direct electrochemical biosensing devices that have wide potential in bio-detection and environmental analyses.

\section{Cancer theranostics}

MXene composites

2D nanomaterials have gained a lot of attention as the ultrathin nanostructure and beneficial physicochemical and biological properties fit for cancer theranostics application [80]. The combination of theranostics, therapeutic functionality and diagnostic imaging allow early diagnosis of cancer or any fatal illness for precision treatment [11, 81]. The surface of 2D nanomaterials can be functionalized with various molecules to activate the theranostics functions in the nanomaterials. Many studies on MXene composites as contrast agent for bio-imaging integrated with photothermal functions have been reported. The first study of MXene composite for cancer theranostics was using tantalum carbide $\left(\mathrm{Ta}_{4} \mathrm{C}_{3}\right)$ nanosheets with manganese oxide $\left(\mathrm{MnO}_{\mathrm{X}}\right)$ that were integrated with soybean phospholipid (SP) to form a new material, $\mathrm{MnO}_{\mathrm{X}} / \mathrm{Ta}_{4} \mathrm{C}_{3}-\mathrm{SP}$ composite [54]. $\mathrm{MnO}_{\mathrm{X}} /$ $\mathrm{Ta}_{4} \mathrm{C}_{3}-\mathrm{SP}$ composite is tested for photothermal tumour ablation, and each layer displayed different functionality. As such, $\mathrm{MnO}_{\mathrm{X}}$ is for tumour microenvironment responsive magnetic resonance imaging (MRI), Ta is desirable for contrast-enhanced computer tomography $(\mathrm{CT})$ scan $[82,83]$ and SP to stabilised the nanocomposite for physiological environments with low cytotoxicity $[54,55,84]$. This study proved that $\mathrm{MnO}_{\mathrm{X}} / \mathrm{Ta}_{4} \mathrm{C}_{3}-$ SP composite successfully achieved contrast-enhanced photoacoustic (PA) imaging and photothermal therapy (PTT) for tumour-growth suppression [54]. Moreover, using Mn outfit conventional $\mathrm{Gd}^{3+}$ (gadolinium)-based agents could result in nephrogenic systemic fibrosis (NSF) in high concentrations $[82,85]$ and Ta element has high atomic number $(Z=73)$ with high X-ray attenuation coefficient (Ta: $4.3 \mathrm{~cm}^{2} \mathrm{~kg}^{-1}$, Au: 5.16 $\mathrm{cm}^{2} \mathrm{~kg}^{-1}$ at $\left.100 \mathrm{eV}\right)[55,83]$. Since then, many studies have been focused on functionalizing MXenes as suitable PA and PTT agents. PA imaging is an emerging imaging modality that is non-invasive, and provides superb contrast, high spatial resolution and deep tissue penetration by detecting the acoustic wave that constructs PA images [84]. Most PA contrast agents can also be used as PTT agents; PTT is a therapeutic modality for thermal ablation of cancers, that has high ablation efficiency, causing minimal damage to normal tissues, and is normally triggered by near-infrared (NIR:>750 nm) laser [86]. The $\mathrm{MnO}_{\mathrm{x}} / \mathrm{Ta}_{4} \mathrm{C}_{3}-\mathrm{SP}$ composite reported a photothermal conversion efficiency (34.9\%) that is greater than $\mathrm{Au}$ nanorods (21\%) [87]. $\mathrm{Ti}_{3} \mathrm{C}_{2}$ MXene was also functionalized with $\mathrm{MnO}_{\mathrm{x}}$ and SP, producing a biocompatible $\mathrm{MnO}_{\mathrm{x}} / \mathrm{Ti}_{3} \mathrm{C}_{2}-\mathrm{SP}$ composite with increased photothermal conversion efficiency of $30.6 \%$ [55]. The modification of $\mathrm{Ta}_{4} \mathrm{C}_{3}$ MXene by replacing the $\mathrm{MnO}_{\mathrm{X}}$ with super-magnetic iron oxide nanoparticles (IONPs) further 
enhanced the $T_{2}$-weighted MR imaging-guided PTT against cancer [56], while $\mathrm{Ti}_{3} \mathrm{C}_{2}$ MXene is functionalized by hydrophobic poly(lactic-co-glycolic acid) (PLGA) and SP, resulting in a PLGA/ $\mathrm{Ti}_{3} \mathrm{C}_{2}$-SP nanocomposite which exhibited strong NIR absorption $(808 \mathrm{~nm})$ and high photothermal conversion [34]. The magnetic nanocomposite, functionalized with $\mathrm{Fe}_{3} \mathrm{O}_{4}$ nanocrystals, exhibited enhanced $T_{2}$ relaxivity of $394.2 \mathrm{mM}^{-1} \mathrm{~s}^{-1}$ for MR imaging and high photothermal conversion efficiency of 48.6\% [32]. Other than tantalum and titanium carbides, niobium carbide has also been studied for its photothermal abilities, such as $\mathrm{Nb}_{2} \mathrm{C}$ nanosheets functionalized with biocompatible polyvinylpyrrolidone (PVP) [57]. The $\mathrm{Nb}_{2} \mathrm{C}$ nanocomposites featured a unique enzyme-responsive biodegradability to human myeloperixodase (hPMO), which generates hypochlorous acid $(\mathrm{HOCl})$ and reactive radical intermediates, that contributes to polymeric or carbon-based materials' degradation [88]. The $\mathrm{PVP} / \mathrm{Nb}_{2} \mathrm{C}$ composite exhibited excellent photothermal conversion efficiency in both NIR-I and NIR-II biowindows (36.4\% and 45.65\%, respectively) [83]. Other than $\mathrm{PVP}, \mathrm{Nb}_{2} \mathrm{C}$ nanosheets were also functionalized with cetanecyltrimethylammonium chloride (CTAC) to create a 'therapeutic mesopore' surface on the nanosheets, which exhibited a high drug loading capacity of $32.57 \%$ and inhibition efficiency of $92.37 \%$ against cancer cells [58].

\section{MXene quantum dots (MQDs)}

As discussed, MXenes are great biosensing tools due to its high electronic conductivity and ease to functionalize, however, standalone MXenes exhibit low photoluminescence (PL) response in aqueous environment, which limit their biological and optical applications. In addition, some MXene nanosheets are still 'too large' for cell permeation, so it is essential for them to have strong PL and are of ultrasmall in size [59, 89]. The breakthrough is MXene quantum dots (MQDs). To date, MQDs have been employed for metal ion sensing, protein detection, electrocatalysis, and energy storage [90-96]. The first production of MQDs yield $\mathrm{Ti}_{3} \mathrm{C}_{2}$ MQDs for multicolour cellular imaging, through facile hydrothermal synthesis $\left(100\right.$ and $\left.120^{\circ} \mathrm{C}\right)$ [59]. Another $\mathrm{Ti}_{3} \mathrm{C}_{2} \mathrm{MQDs}$ were prepared through a fluorine-free synthesis technique which used mechanical force-assisted liquid exfoliation; bulk $\mathrm{Ti}_{3} \mathrm{AlC}_{2}$ was ultrasonically treated with a probe in tetrabutylammonium hydroxide (TBAOH) etching solution [60]. $\mathrm{Ti}_{3} \mathrm{C}_{2}$ MQDs exhibited large extinction coefficient of $52.8 \mathrm{Lg}^{-1} \mathrm{~cm}^{-1}$ at NIR range $(808 \mathrm{~nm})$, which is ideal for photothermal imaging. Also, they displayed high photothermal conversion efficiency of $52.2 \%$, and showed great biocompatibility in vitro and in vivo [60]. Another study of $\mathrm{Ti}_{2} \mathrm{~N}$ QDs exhibit excellent photothermal conversion efficiency of $48.62 \%$ and $45.51 \%$ in NIR-I and NIR-II biowindows with great biodegradable function, therefore, is best candidate as PA imaging-guide PTT agent [61]. MQDs can also be used as a fluorescence imaging probe, as example of fluorescence emission of $\mathrm{Nb}_{2} \mathrm{C}$ MQDs [62]. These MQDs were reported to display excellent chemical stability, biocompatibility, and possessed strong resistance to photobleaching [62].

Based on these theranostic studies of MXenes [49, 51, 52, 54], they show great potential as contrast agents in various bio-imaging and excellent therapeutic agents for PTT treatment. Most studied MXenes exhibited better photothermal conversion efficiency, compared to conventional Au nanorods [50]. Also, Ta-based MXene show great 
potential as MRI contrast agents [50], which can replace traditional Gd-based contrast agents that can destabilise and produce bare $\mathrm{Gd}^{3+}$ ions that are harmful to our bodies. Tantalum carbides can oxidize into tantalum oxides, but the systemic toxicity of tantalum oxide is quite low due to its poor solubility. Tantalum carbide is also comparable to $\mathrm{Au}$ nanoparticles as $\mathrm{X}$-ray imaging contrast agent since they both possess similar X-ray attenuation coefficient. Overall, MXenes exhibit low cytotoxicity and good biodegradability for effective cancer treatment and safe human consumption.

\section{Drug delivery}

2D nanomaterials ranging from 1 to $100 \mathrm{~nm}$ which perfectly suit to the need of drug delivery system [97]. Due to their size, nanomaterials can travel more freely inside the human body, compared to larger molecules. Moreover, traditional drug administration requires high drug dosages for achieving therapeutic levels, which in turn caused toxicity to normal cells and tissues, and resistance of multiple drugs $[98,99]$. This provide the motivation of nanomedicines as delivery agents in targeting specific tissues, by encapsulating or attaching to specified drugs [100]. MXenes have potential as great drug delivery systems, as their 2D planar structure and unique physicochemical properties could endorse them for drug loading for precision treatment [63]. Modified ultrathin $\mathrm{Ti}_{3} \mathrm{C}_{2}$ nanosheets are able to be transported easily throughout the blood vessels [34], and its large surface area enable efficient coating of anticancer drug doxorubicin (Dox) and show high drug-releasing percentages in acidic environment, leading to efficient eradication of the tumour [101]. Upon near-infrared (NIR) irradiation at $808 \mathrm{~nm}$, the drug release percentage increased by $23.5 \%$ at very acidic condition [101].

To efficiently control the rate of drug release, MXene nanomaterials were integrated into cellulose hydrogel [64]. This type of MXene hydrogel shows the efficient releasing rate accelerated by NIR irradiation in addition to its illumination function for enlarging the pore dimensions of the composite hydrogel, accelerating the release of Dox [64]. $\mathrm{Ti}_{3} \mathrm{C}_{2}$ /polyacrylamide (PAM) hydrogels polymerised of $\mathrm{Ti}_{3} \mathrm{C}_{2}$ nanosheets and acrylamide show better swelling properties as compared to traditional $N, N$-methylene bisacrylamide/polyacrylamide (BIS/PAM) hydrogel, effectively increasing the uptake of drug $[65,102]$. The reason for the brilliant drug uptake in the MXene-composite hydrogel is aided by the hydrogen-bonding interactions between the water and hydrophilic surface functional groups of MXenes and the hydrophilic groups $\left(-\mathrm{CONH}_{2}\right)$ of the polymer chains. The $\mathrm{Ti}_{3} \mathrm{C}_{2} / \mathrm{PAM}$ hydrogels tend to swell for a much longer time compared to BIS/PAM hydrogels, indicating a higher drug loading capacity [65]. Also, the drugreleasing percentage of $\mathrm{Ti}_{3} \mathrm{C}_{2} / \mathrm{PAM}$ hydrogels increased to $62.1-81.4 \%$, compared to BIS/PAM hydrogels (45\%).

Recently, magnetic nanomaterials have been introduced into drug delivery systems to increase the controllability of the nanocarriers especially under magnetic field [103, 104], example is combination of cobalt nanowires (CoNWs) and $\mathrm{Ti}_{3} \mathrm{C}_{2}$ nanosheets to form $\mathrm{Ti}_{3} \mathrm{C}_{2}$-CoNWs metal-semiconductor heterojunction [66]. The $\mathrm{Ti}_{3} \mathrm{C}_{2}$-based nanocarrier heterojunction exhibited an increased drug loading efficacy, with increasing Doxnanocarrier ratios. At the highest mass ratio of 3 , the $\mathrm{DOX} / \mathrm{Ti}_{3} \mathrm{C}_{2}$-CoNWs nanocarrier heterojunction exhibited the highest drug loading capacity of $225.05 \%$, which is much higher than single $\mathrm{Ti}_{3} \mathrm{C}_{2}$ nanosheets $(84 \%)$ and most spherical drug delivery nanocarriers 
$(10-30 \%)[105,106]$. Under acidic conditions, the solubility and the hydrophilicity of the Dox drug increase, prompting an acceleration of drug release [107]. Additionally, NIR irradiation of the Dox-loaded nanocarrier further increased the drug release percentage [66].

As studied, bare $\mathrm{Ti}_{3} \mathrm{C}_{2}$ MXene has been proven to be far superior for drug release compared to classic spherical systems, with an increase of $>50 \%$ in drug release percentage. Modifying the $\mathrm{Ti}_{3} \mathrm{C}_{2}$ nanosheets with hydrogel or magnetic semiconductors further improved drug release percentage by at least $\sim 30 \%$ and $\sim 200 \%$, respectively. Hence, $\mathrm{Ti}_{3} \mathrm{C}_{2}$ MXene demonstrates a promising drug delivery nanocarrier, pristine or modified, for precision drug delivery and cancer treatment that is potentially way better than current nano-based drug delivery systems.

\section{Antimicrobial activity}

The high surface area to volume ratio and ease of surface functionalization has open a door for antimicrobial application to enable reaction with bacteria membranes [108]. Generally, nanomaterials do not trigger bacterial resistance due to their high membrane permeability, biocompatibility and potential for multiple antibacterial actions [108]. Prior to MXenes, the mode of action of graphene-based nanomaterials in antimicrobial application function by production of reactive oxygen species (ROS) and direct contact with bacteria membrane [109-113]. The first $\mathrm{Ti}_{3} \mathrm{C}_{2}$ MXene colloidal solution for its antibacterial properties need a high concentration dose of $200 \mu \mathrm{g} \mathrm{mL} \mathrm{m}^{-1}$ to give positive inhibition $[67,68]$. Nevertheless, modified $\mathrm{Ti}_{3} \mathrm{C}_{2}$ modified with polyvinylidene fluoride (PVDF) greatly improve the antimicrobial activities [68].

Another fabrication of $\mathrm{Ti}_{3} \mathrm{C}_{2} /$ chitosan composite nanofibers crosslinked with glutaraldehyde via electrospinning show more than 62\% reduction of microbes [69]. Comparison of $\mathrm{Ti}_{2} \mathrm{C}$ and $\mathrm{Ti}_{3} \mathrm{C}_{2}$ MXenes against $E$. coli show that only $\mathrm{Ti}_{3} \mathrm{C}_{2}$ exhibit antibacterial properties [70], and the further examination of these proved that smaller-sized nanosheets demonstrated higher antibacterial activity [71]. In addition, the aggregation of nanomaterials due to its cationic charge was improved by combining $\mathrm{Ti}_{3} \mathrm{C}_{2}$ flakes with cationic polymeric poly-L-lysine (PLL), which changed the negative charge $(-5.6 \mathrm{mV})$ of $\mathrm{Ti}_{3} \mathrm{C}_{2}$ flakes to $+44.9 \mathrm{mV}\left(1: 1, \mathrm{PLL}: \mathrm{Ti}_{3} \mathrm{C}_{2}\right)$ to extremely reduce the flocculation degree of the MXene flakes [22].

Another study has proposed that the unique features of MXene nanosheets that have sharp edges and small size can cut through the bacterial cell wall, which results in the release of bacteria DNA and eventually bacteria dispersion [71]. To date, the only study of antifungal properties of MXene was reported on $\mathrm{Ti}_{3} \mathrm{C}_{2}$ MXene on Trichoderma reesei (T. reesei) [20]. The results of this study demonstrated the inhibition of hyphae growth of $T$. reesei with the presence of delaminated MXene $\left(\mathrm{d}-\mathrm{Ti}_{3} \mathrm{C}_{2}\right)$, which exhibited similar results with antifungal medication amphotericin-B. The MXene nanosheets may also inhibit spore germination due to the sharp lamellar edges of the nanosheets. Hence, this study proved that $\mathrm{Ti}_{3} \mathrm{C}_{2}$ MXene can disrupt the life cycle of fungi and showed great potential of MXenes as promising antifungal agents.

Although the bacterial killing mechanism of MXenes are currently being investigated, the long-term colloidal stability of the MXene is still not fully understood. Generally, agglomeration or oxidation of $2 \mathrm{D}$ nanomaterials will cause the loss of its $2 \mathrm{D}$ 
characteristic structure and will directly affect their antimicrobial efficacy. Ideally, MXenes should be stable for long enough to induce its bactericidal properties, but also remain biocompatible. Hence, more research on improving the stability of MXene in physiological conditions should be carried out to increase its application as an antimicrobial agent.

\section{Conclusions and future outlooks}

In this review, the general overview of structural organization of 2D MXenes is discussed. Various syntheses methods: top-down or bottom-up, fluorine-based or fluorinefree etching methods, are reviewed to produce biocompatible MXenes. Synthesised MXenes can then be further modified to enhance the biocompatibility/biodegradability and reduce the cytotoxicity of the 2D materials for specific biomedical applications. MXenes possess an exceptional potential for drug delivery, antimicrobial properties, tissue engineering, high surface area to volume ratio, as well as wide-ranging near-infrared absorption. These qualities make MXenes one of the most promising material for bioapplications. The chemistry of MXenes allows possible application in area that had not been explored such as surface coating of medical catheter, mask, and gloves because of their excellent antimicrobial activity. Flexibility and elasticity of MXenes have also been reported [114], mainly as thin films for electronic devices, which is also a suitable trait for surface coating as we do not want the surface of the catheter/ mask/gloves to harden. It is also possible to develop highly effective and non-invasive anticancer therapy because of their photodynamic/photo thermal chemotherapy synthetic effect. Nevertheless, research on the biocompatibility of MXene-based materials is still very limited, more attention should be focused on the systematic evaluation and adjustment of toxicity of MXene-based materials. For example, cell uptake behaviour, cytotoxicity mechanism, in vitro and in vivo MXenes should also be prudently investigated. Therefore, physiological effects of MXenes need to be fully understood, since MXene-based materials may accumulate in our body system, and long-term accumulation could lead to potential toxicity. Till date, reports on the interaction of MXene with human physiological system are not available. Previous findings of other 2D nanomaterials, such as graphene, on their behaviours in biological/physiological conditions can be referred to when conducting studies on MXenes. For example, graphene's clearance behaviours can be referred to when studying the clearance pathway of MXenes, since this pathway is important to be fully understood for the materials to be deemed safe for clinical use. Prudent investigation of MXene for clinical use is an area that had not be explored. Also, more environmentally friendly preparation approaches need to be investigated to ensure minimal hazard to environment upon release. Through these studies, a rapid growth in the synthesis of new family of MXenes and their bright perspective in biomedical applications can be expected. This review showcases the wide range of applications of MXenes, their derivatives, and MXene-based composites in biosensors, cancer theranostics, cancer biomarkers drug delivery, and antimicrobial activity. We note that the use of MXenes in biomedical research is in its early stage, and systematic guidelines are required before biomedical applications of MXene-based materials can be achieved. 


\section{Acknowledgements}

We acknowledge the research funding support from Malaysia Ministry of Higher Education Malaysia under Fundamental Research Grant Scheme (FRGS) with a reference number of FRGS/1/2018/STG05/UTHM/02/3 or FRGS Vot No. K106. The authors thank Ahmad Nasrull Mohamed for preparing the FE-SEM images.

\section{Authors' contributions}

AZ: writing the original draft, GPL: writing —original draft and data curation, NLM: writing the original draft and reviewing, KST: writing original draft and reviewing, CFS: conceptualization, writing and editing the draft. All authors read and approved the final manuscript.

\section{Funding}

The writing work is funded by Malaysia Ministry of Education under Fundamental Research Grant Scheme (FRGS) with a Reference Number of FRGS/1/2018/STG05/UTHM/02/3 or FRGS Vot No. K106.

\section{Availability of data and materials}

Not applicable.

\section{Declarations}

Ethics approval and consent to participate

Not applicable.

\section{Consent for publication}

Not applicable.

\section{Competing interests}

The authors declare that they have no known competing financial interests or personal relationships that could have appeared to influence the work reported in this paper.

\section{Author details}

${ }^{1}$ Biosensor and Bioengineering Lab, Microelectronics and Nanotechnology-Shamsuddin Research Centre, Institute for Integrated Engineering, Universiti Tun Hussein Onn Malaysia, Parit Raja, 86400 Batu Pahat, Johor, Malaysia. ${ }^{2}$ Faculty of Electrical and Electronic Engineering, Universiti Tun Hussein Onn Malaysia, Parit Raja, 86400 Batu Pahat, Johor, Malaysia.

${ }^{3}$ Faculty of Science and Marine Environment, Universiti Malaysia Terengganu, 21030 Kuala Nerus, Terengganu, Malaysia.

Received: 18 December 2020 Accepted: 22 March 2021

Published online: 01 April 2021

\section{References}

1. Shinde PV, Singh MK. Synthesis, characterization, and properties of graphene analogs of 2D material. Fundam Sens Appl 2D Mater. 2019;5:91-143.

2. Li Z, Wang L, Sun D, Zhang Y, Liu B, Hu Q, Zhou A. Synthesis and thermal stability of two-dimensional carbide MXene Ti3C2. Mater Sci Eng B. 2015;191:33-40.

3. Kang MH, Lee D, Sung J, Kim J, Kim BH, Park J. Structure and chemistry of 2D materials. Comprehens Nanosci Nanotechnol. 2019;1-5:55-90.

4. Gogotsi Y, Anasori B. The rise of MXenes. ACS Nano. 2019;13:8491-4.

5. Tan C, Cao X, Wu XJ, He Q, Yang J, Zhang X, Chen J, Zhao W, Han S, Nam GH, et al. Recent advances in ultrathin two-dimensional nanomaterials. Chem Rev. 2017;117:6225-331.

6. Kannan K, Sadasivuni KK, Abdullah AM, Kumar B. Current trends in MXene-based nanomaterials for energy storage and conversion system: a mini review. Catalysts. 2020;10:1-28.

7. Guo Y, Zhong M, Fang Z, Wan P, Yu G. A wearable transient pressure sensor made with mxene nanosheets for sensitive broad-range human-machine interfacing. Nano Lett. 2019;19:1143-50.

8. Wang Z, Zhu W, Qiu Y, Yi X, Von Dem Bussche A, Kane A, Gao H, Koski K, Hurt R. Biological and environmental interactions of emerging two-dimensional nanomaterials. Chem Soc Rev. 2016;45:1750-80.

9. Huang Z, Cui X, Li S, Wei J, Li P, Wang Y, Lee CS. Two-dimensional MXene-based materials for photothermal therapy. Nanophotonics. 2020;9:2233-49.

10. Naguib M, Kurtoglu M, Presser V, Lu J, Niu J, Heon M, Hultman L, Gogotsi Y, Barsoum MW. Two-dimensional nanocrystals produced by exfoliation of $\mathrm{Ti}_{3} \mathrm{AlC}_{2}$. Adv Mater. 2011;23:4248-53.

11. Sundaram A, Ponraj JS, Ponraj JS, Wang C, Peng WK, Manavalan RK, Dhanabalan SC, Zhang H, Gaspar J. Engineering of 2D transition metal carbides and nitrides MXenes for cancer therapeutics and diagnostics. J Mater Chem B. 2020;8:4990-5013.

12. Huang $H$, Jiang $R$, Feng $Y$, Ouyang $H$, Zhou N, Zhang $X$, Wei $Y$. Recent development and prospects of surface modification and biomedical applications of MXenes. Nanoscale. 2020;12:1325-38.

13. Wang Y, Feng W, Chen Y. Chemistry of two-dimensional MXene nanosheets in theranostic nanomedicine. Chin Chem Lett. 2020;31:937-46.

14. Huang K, Li Z, Lin J, Han G, Huang P. Two-dimensional transition metal carbides and nitrides (MXenes) for biomedical applications. Chem Soc Rev. 2018:47:5109-24. 
15. Ibrahim Y, Mohamed A, Abdelgawad AM, Eid K, Abdullah AM, Elzatahry A. The recent advances in the mechanical properties of self-standing two-dimensional MXene-based nanostructures: deep insights into the supercapacitor. Nanomaterials. 2020;10:10.

16. Bai L, Yi W, Sun T, Tian Y, Zhang P, Si J, Hou X, Hou J. Surface modification engineering of two-dimensional titanium carbide for efficient synergistic multitherapy of breast cancer. J Mater Chem B. 2020;8:6402-17.

17. Shao B, Liu Z, Zeng G, Wang H, Liang Q, He Q, Cheng M, Zhou C, Jiang L, Song B. Two-dimensional transition metal carbide and nitride (MXene) derived quantum dots (QDs): Synthesis, properties, applications and prospects. J Mater Chem A. 2020;8:7508-35.

18. Zhou A. Methods of MAX-phase synthesis and densification-II Advances in science and technology of Mn+ $1 \mathrm{AXn}$ phases. New York: Elsevier; 2012. p. 21-46.

19. Venkateshalu S, Grace AN. MXenes_a new class of $2 D$ layered materials: Synthesis, properties, applications as supercapacitor electrode and beyond. Appl Mater Today. 2020;18:100509.

20. Lim GP, Soon CF, Morsin M, Ahmad MK, Nayan N, Tee KS. Synthesis, characterization and antifungal property of Ti3C2Tx MXene nanosheets. Ceram Int. 2020;46(12):20306-12.

21. Pang J, Mendes RG, Bachmatiuk A, Zhao L, Ta HQ, Gemming T, Liu H, Liu Z, Rummeli MH. Applications of 2D MXenes in energy conversion and storage systems. Chem Soc Rev. 2019;48:72-133.

22. Rozmysłowska-Wojciechowska A, Mitrzak J, Szuplewska A, Chudy M, Woźniak J, Petrus M, Wojciechowski T, Vasilchenko AS, Jastrzebska AM. Engineering of 2D Ti3C2 MXene surface charge and its influence on biological properties. Materials. 2020;13:1-18.

23. Ghidiu M, Lukatskaya MR, Zhao MQ, Gogotsi Y, Barsoum MW. Conductive two-dimensional titanium carbide "clay" with high volumetric capacitance. Nature. 2015;516:78-81.

24. Liu F, Zhou A, Chen J, Jia J, Zhou W, Wang L, Hu Q. Preparation of Ti 3 C 2 and Ti 2 C MXenes by fluoride salts etching and methane adsorptive properties. Appl Surf Sci. 2017;416:781-9.

25. Halim J, Lukatskaya MR, Cook KM, Lu J, Smith CR, Näslund LÅ, May SJ, Hultman L, Gogotsi Y, Eklund P, Barsoum MW. Transparent conductive two-dimensional titanium carbide epitaxial thin films. Chem Mater. 2014;26:2374-81.

26. Pang SY, Wong YT, Yuan S, Liu Y, Tsang MK, Yang Z, Huang H, Wong WT, Hao J. Universal Strategy for HF-free facile and rapid synthesis of two-dimensional MXenes as multifunctional energy materials. J Am Chem Soc. 2019;141:9610-6.

27. Li T, Yao L, Liu Q, Gu J, Luo R, Li J, Yan X, Wang W, Liu P, Chen B, et al. Fluorine-free synthesis of high-purity Ti3C2TX ( $\mathrm{T}=\mathrm{OH}, \mathrm{O}$ ) via alkali treatment. Angewandte Chemie - International Edition. 2018;57:6115-9.

28. Urbankowski P, Anasori B, Makaryan T, Er D, Kota S, Walsh PL, Zhao M, Shenoy VB, Barsoum MW, Gogotsi Y. Synthesis of two-dimensional titanium nitride Ti4N3 (MXene). Nanoscale. 2016;8:11385-91.

29. Soleymaniha M, Shahbazi MA, Rafieerad AR, Maleki A, Amiri A. Promoting role of MXene nanosheets in biomedical sciences: therapeutic and biosensing innovations. Adv Healthcare Mater. 2019;8:1-26.

30. Anasori B, Lukatskaya MR, Gogotsi Y. 2D metal carbides and nitrides (MXenes) for energy storage. Nat Rev Mater. 2017;2:78.

31. Mashtalir O, Naguib M, Mochalin VN, Dall'Agnese Y, Heon M, Barsoum MW, Gogotsi Y. Intercalation and delamination of layered carbides and carbonitrides. Nat Commun. 2013:4:1-7.

32. Mashtalir O, Lukatskaya MR, Zhao MQ, Barsoum MW, Gogotsi Y. Amine-assisted delamination of Nb2C MXene for li-ion energy storage devices. Adv Mater. 2015;27:3501-6.

33. Naguib M, Unocic RR, Armstrong BL, Nanda J. Large-scale delamination of multi-layers transition metal carbides and carbonitrides "mXenes." Dalton Trans. 2015;44:9353-8.

34. Lin H, Wang X, Yu L, Chen Y, Shi J. Two-dimensional ultrathin MXene ceramic nanosheets for photothermal conversion. Nano Lett. 2017;17:384-91.

35. Yang B, Chen Y, Shi J. Material chemistry of two-dimensional inorganic nanosheets in cancer theranostics. Chem. 2018:4:1284-313.

36. Verger L, Xu C, Natu V, Cheng HM, Ren W, Barsoum MW. Overview of the synthesis of MXenes and other ultrathin 2D transition metal carbides and nitrides. Curr Opin Solid State Mater Sci. 2019;23:149-63.

37. Xu C, Wang L, Liu Z, Chen L, Guo J, Kang N, Ma XL, Cheng HM, Ren W. Large-area high-quality 2D ultrathin Mo2C superconducting crystals. Nat Mater. 2015;14:1135-41.

38. Xiao X, Yu H, Jin H, Wu M, Fang Y, Sun J, Hu Z, Li T, Wu J, Huang L, et al. Salt-templated synthesis of 2D metallic MoN and other nitrides. ACS Nano. 2017;11:2180-6.

39. Zhang Z, Zhang F, Wang H, Ho Chan C, Lu W, Dai JY. Substrate orientation-induced epitaxial growth of face centered cubic Mo2C superconductive thin film. J Mater Chem C. 2017;5:10822-7.

40. Zhang CJ, Pinilla S, McEvoy N, Cullen CP, Anasori B, Long E, Park SH, Seral-Ascaso A, Shmeliov A, Krishnan D, et al. Oxidation stability of colloidal two-dimensional titanium carbides (MXenes). Chem Mater. 2017;29:4848-56.

41. Pham P, Yeom G. Recent advances in doping of molybdenum disulfide: industrial applications and future prospects. Adv Mater. 2016;28:14.

42. Vitale F, Driscoll N, Murphy B. Biomedical Applications of MXenes. In: Anasori B, Gogotsi Y, editors. 2D Metal Carbides and nitrides (MXenes): structure, properties and applications. Cham: Springer International Publishing; 2019. p. 503-24.

43. Lin $\mathrm{H}$, Chen Y, Shi J. Insights into 2D MXenes for versatile biomedical applications: current advances and challenges ahead. Adv Sci (Weinh). 2018;5(10):1800518.

44. Wang F, Yang $\mathrm{CH}$, Duan M, Tang Y, Zhu JF. TiO2 nanoparticle modified organ-like Ti3C2 MXene nanocomposite encapsulating hemoglobin for a mediator-free biosensor with excellent performances. Biosens Bioelectron. 2015;74:1022-8.

45. Liu H, Duan C, Yang C, Shen W, Wang F, Zhu Z. A novel nitrite biosensor based on the direct electrochemistry of hemoglobin immobilized on MXene-Ti3C2. Sens Actuators, B Chem. 2015;218:60-6.

46. Rakhi RB, Nayuk P, Xia C, Alshareef HN. Novel amperometric glucose biosensor based on MXene nanocomposite. Sci Rep. 2016;6:1-10. 
47. Wu M, Zhang Q, Fang Y, Deng C, Zhou F, Zhang Y, Wang X, Tang Y, Wang Y. Polylysine-modified MXene nanosheets with highly loaded glucose oxidase as cascade nanoreactor for glucose decomposition and electrochemical sensing. J Colloid Interface Sci. 2020;87:66.

48. Wu L, Lu X, Dhanjai H, Wu ZS, Dong Y, Wang X, Zheng S, Chen J. 2D transition metal carbide MXene as a robust biosensing platform for enzyme immobilization and ultrasensitive detection of phenol. Biosensors Bioelectr. 2018;107:69-75

49. Koyappayil A, Chavan SG, Mohammadniaei M, Go A, Hwang SY, Lee MH. $\beta$-Hydroxybutyrate dehydrogenase decorated MXene nanosheets for the amperometric determination of $\beta$-hydroxybutyrate. Microchim Acta. 2020;187:23.

50. Kumar S, Lei Y, Alshareef NH, Quevedo-Lopez MA, Salama KN. Biofunctionalized two-dimensional Ti3C2 MXenes for ultrasensitive detection of cancer biomarker. Biosens Bioelectron. 2018;121:243-9.

51. Wu Q, Li N, Wang Y, Liu Y, Xu Y, Wei S, Wu J, Jia G, Fang X, Chen F, Cui X. A 2D transition metal carbide MXene-based SPR biosensor for ultrasensitive carcinoembryonic antigen detection. Biosensors Bioelectr. 2019;144:111697.

52. Wu Q, Li N, Wang Y, Xu Y, Wu J, Jia G, Ji F, Fang X, Chen F, Cui X. Ultrasensitive and selective determination of carcinoembryonic antigen using multifunctional ultrathin amino-functionalized Ti(3)C(2)-MXene nanosheets. Anal Chem. 2020;92(4):3354-60.

53. Zhou S, Gu C, Li Z, Yang L, He L, Wang M, Huang X, Zhou N, Zhang Z. Ti3C2Tx MXene and polyoxometalate nanohybrid embedded with polypyrrole: ultra-sensitive platform for the detection of osteopontin. Appl Surf Sci. 2019:498:143889.

54. Dai C, Chen Y, Jing X, Xiang L, Yang D, Lin H, Liu Z, Han X, Wu R. Two-dimensional tantalum carbide (MXenes) composite nanosheets for multiple imaging-guided photothermal tumor ablation. ACS Nano. 2017;1 1:12696-712.

55. Dai C, Lin H, Xu G, Liu Z, Wu R, Chen Y. Biocompatible 2D titanium carbide (MXenes) composite nanosheets for pH-responsive mri-guided tumor hyperthermia. Chem Mater. 2017;29:8637-52.

56. Liu Z, Lin H, Zhao M, Dai C, Zhang S, Peng W, Chen Y. 2D superparamagnetic tantalum carbide composite MXenes for efficient breast-cancer theranostics. Theranostics. 2018;8:1648-64.

57. Lin H, Gao S, Dai C, Chen Y, Shi J. A two-dimensional biodegradable niobium carbide (MXene) for photothermal tumor eradication in NIR-I and NIR-II biowindows. J Am Chem Soc. 2017;139:16235-47.

58. Han X, Jing X, Yang D, Lin H, Wang Z, Ran H, Li P, Chen Y. Therapeutic mesopore construction on 2D Nb2C MXenes for targeted and enhanced chemo-photothermal cancer therapy in NIR-II biowindow. Theranostics. 2018:8:4491-508.

59. Xue Q, Zhang H, Zhu M, Pei Z, Li H, Wang Z, Huang Y, Huang Y, Deng Q, Zhou J, et al. Photoluminescent Ti3C2 MXene quantum dots for multicolor cellular imaging. Adv Mater. 2017;29:1-6.

60. Yu X, Cai X, Cui H, Lee SW, Yu XF, Liu B. Fluorine-free preparation of titanium carbide MXene quantum dots with high near-infrared photothermal performances for cancer therapy. Nanoscale. 2017:9:17859-64.

61. Shao J, Zhang J, Jiang C, Lin J, Huang P. Biodegradable titanium nitride MXene quantum dots for cancer phototheranostics in NIR-I/Il biowindows. Chem Eng J. 2020;400:126009.

62. Yang G, Zhao J, Yi S, Wan X, Tang J. Biodegradable and photostable Nb2C MXene quantum dots as promising nanofluorophores for metal ions sensing and fluorescence imaging. Sens Actuators, B Chem. 2020;309:127735.

63. Han X, Huang J, Lin H, Wang Z, Li P, Chen Y. 2D ultrathin MXene-based drug-delivery nanoplatform for synergistic photothermal ablation and chemotherapy of cancer. Adv Healthcare Mater. 2018;7:1-13.

64. Xing C, Chen S, Liang X, Liu Q, Qu M, Zou Q, Li J, Tan H, Liu L, Fan D, Zhang H. Two-dimensional MXene (Ti3C2)integrated cellulose hydrogels: toward smart three-dimensional network nanoplatforms exhibiting lightinduced swelling and bimodal photothermal/chemotherapy anticancer activity. ACS Appl Mater Interfaces. 2018;10:27631-43.

65. Zhang P, Yang XJ, Li P, Zhao Y, Niu QJ. Fabrication of novel MXene (Ti3C2)/polyacrylamide nanocomposite hydrogels with enhanced mechanical and drug release properties. Soft Matter. 2019;16:162-9.

66. Liu Y, Han Q, Yang W, Gan X, Yang Y, Xie K, Xie L, Deng Y. Two-dimensional MXene/cobalt nanowire heterojunction for controlled drug delivery and chemo-photothermal therapy. Mater Sci Eng, C. 2020;116:111212.

67. Rasool K, Helal M, Ali A, Ren CE, Gogotsi Y, Mahmoud KA. Antibacterial activity of Ti3C2Tx MXene. ACS Nano. 2016;10:3674-84

68. Rasool K, Mahmoud KA, Johnson DJ, Helal M, Berdiyorov GR, Gogotsi Y. Efficient antibacterial membrane based on two-dimensional Ti3C2Tx (MXene) nanosheets. Sci Rep. 2017;7:1-11.

69. Mayerberger EA, Street RM, McDaniel RM, Barsoum MW, Schauer CL. Antibacterial properties of electrospun Ti3C2Tz (MXene)/chitosan nanofibers. RSC Adv. 2018;8:35386-94.

70. Jastrzębska AM, Karwowska E, Wojciechowski T, Ziemkowska W, Rozmysłowska A, Chlubny L, Olszyna A. The atomic structure of $\mathrm{Ti}_{2} \mathrm{C}$ and $\mathrm{Ti}_{3} \mathrm{C}_{2}$ MXenes is responsible for their antibacterial activity toward $E$. coli bacteria. J Mater Eng Perform. 2019;28:1272-7.

71. Arabi Shamsabadi A, Sharifian M, Anasori B, Soroush M. Antimicrobial mode-of-action of colloidal $\mathrm{Ti}_{3} \mathrm{C}_{2} \mathrm{Tx} \mathrm{MX}$ ene nanosheets. ACS Sustainable Chem Eng. 2018;6:16586-96.

72. Lipatov A, Sinitskii A. Electronic and mechanical properties of MXenes derived from single-flake measurements. Metal Carbides Nitrides. 2019;58:301-25.

73. Khazaei M, Arai M, Sasaki T, Chung CY, Venkataramanan NS, Estili M, Sakka Y, Kawazoe Y. Novel electronic and magnetic properties of two-dimensional transition metal carbides and nitrides. Adv Func Mater. 2013;23:2185-92.

74. Grisham MB. Methods to detect hydrogen peroxide in living cells: Possibilities and pitfalls. Comp Biochem Physiol A Mol Integr Physiol. 2013;165(4):429-38

75. Wang $Y$, Ma X, Wen Y, Xing Y, Zhang Z, Yang H. Direct electrochemistry and bioelectrocatalysis of horseradish peroxidase based on gold nano-seeds dotted $\mathrm{TiO}_{2}$ nanocomposite. Biosens Bioelectron. 2010;25:2442-6.

76. Anku WW, Mamo MA, Govender PP. Phenolic compounds in water: sources, reactivity, toxicity and treatment methods. Phenolic compounds-natural sources, importance and applications. Berlin: Springer; 2017, p 420-43.

77. Smith CA. Good medicine A quick-start guide to managing pharmaceutical waste. Health Facilit Manag. 2010;23:40-3. 
78. Xu B, Zhu M, Zhang W, Zhen X, Pei Z, Xue Q, Zhi C, Shi P. Ultrathin MXene-micropattern-based field-effect transistor for probing neural activity. Adv Mater. 2016;28:3333-9.

79. Gimba ERP, Brum MCM, De Moraes GN. Full-length osteopontin and its splice variants as modulators of chemoresistance and radioresistance (Review). Int J Oncol. 2019;54:420-30.

80. Liu Z, Zhao M, Lin H, Dai C, Ren C, Zhang S, Peng W, Chen Y. 2D magnetic titanium carbide MXene for cancer theranostics. J Mater Chem B. 2018;6:3541-8.

81. Chen X, Wong STC. Cancer Theranostics: An Introduction. Cancer Theranost. 2014;55:3-8.

82. Pan X, Siewerdsen J, La Riviere PJ, Kalender WA. Anniversary paper: development of X-ray computed tomography: The role of Medical Physics and AAPM from the 1970s to present. Med Phys. 2008;35:3728-39.

83. Lee N, Choi SH, Hyeon T. Nano-sized CT contrast agents. Adv Mater. 2013;25:2641-60.

84. Fu Q, Zhu R, Song J, Yang H, Chen X. Photoacoustic imaging: contrast agents and their biomedical applications. Adv Mater. 2019;31:1-31.

85. Broome DR, Girguis MS, Baron PW, Cottrell AC, Kjellin I, Kirk GA. Gadodiamide-associated nephrogenic systemic fibrosis: Why radiologists should be concerned. Am J Roentgenol. 2007;188:586-92.

86. Chen M, Tang S, Guo Z, Wang X, Mo S, Huang X, Liu G, Zheng N. Core-shell Pd@Au nanoplates as theranostic agents for in-vivo photoacoustic imaging, CT imaging, and photothermal therapy. Adv Mater. 2014;26:8210-6.

87. Zeng J, Goldfeld D, Xia Y. A plasmon-assisted optofluidic (PAOF) system for measuring the photothermal conversion efficiencies of gold nanostructures and controlling an electrical switch. Angewandte Chemie - International Edition. 2013;52:4169-73.

88. Kagan VE, Konduru NV, Feng W, Allen BL, Conroy J, Volkov Y, Vlasova II, Belikova NA, Yanamala N, Kapralov A, et al. Carbon nanotubes degraded by neutrophil myeloperoxidase induce less pulmonary inflammation. Nat Nanotechnol. 2010:5:354-9.

89. Medintz IL, Uyeda HT, Goldman ER, Mattoussi H. Quantum dot bioconjugates for imaging, labelling and sensing. Nat Mater. 2005:4:435-46.

90. Xu Q, Ding L, Wen Y, Yang W, Zhou H, Chen X, Street J, Zhou A, Ong WJ, Li N. High photoluminescence quantum yield of $18.7 \%$ by using nitrogen-doped $\mathrm{Ti}_{3} \mathrm{C}_{2}$ MXene quantum dots. J Mater Chem C. 2018;6:6360-9.

91. Zhang Q, Sun Y, Liu M, Liu Y. Selective detection of Fe ${ }^{3+}$ ions based on fluorescence MXene quantum dots via a mechanism integrating electron transfer and inner filter effect. Nanoscale. 2020;12:1826-32.

92. Guo Z, Zhu X, Wang S, Lei C, Huang Y, Nie Z, Yao S. Fluorescent Ti3C2 MXene quantum dots for an alkaline phosphatase assay and embryonic stem cell identification based on the inner filter effect. Nanoscale. 2018;10:19579-85.

93. Cai G, Yu Z, Tong P, Tang D. Ti3C2 MXene quantum dot-encapsulated liposomes for photothermal immunoassays using a portable near-infrared imaging camera on a smartphone. Nanoscale. 2019;11:15659-67.

94. Yang X, Jia Q, Duan F, Hu B, Wang M, He L, Song Y, Zhang Z. Multiwall carbon nanotubes loaded with MoS 2 quantum dots and MXene quantum dots: non-Pt bifunctional catalyst for the methanol oxidation and oxygen reduction reactions in alkaline solution. Appl Surf Sci. 2019;464:78-87.

95. Cheng H, Ding LX, Chen GF, Zhang L, Xue J, Wang H. Molybdenum carbide nanodots enable efficient electrocatalytic nitrogen fixation under ambient conditions. Adv Mater. 2018;30:1-7.

96. Zhou X, Qin Y, He X, Li Q, Sun J, Lei Z, Liu ZH. Ti3C2TX Nanosheets/Ti3C2Tx quantum Dots/RGO (reduced graphene oxide) fibers for an all-solid-state asymmetric supercapacitor with high volume energy density and good flexibility. ACS Appl Mater Interfaces. 2020;12:11833-42.

97. Patra JK, Das G, Fraceto LF, Campos EVR, Rodriguez-Torres MDP, Acosta-Torres LS, Diaz-Torres LA, Grillo R, Swamy MK, Sharma S, et al: Nano based drug delivery systems: Recent developments and future prospects 10 Technology 1007 Nanotechnology 03 Chemical Sciences 0306 Physical Chemistry (incl. Structural) 03 Chemical Sciences 0303 Macromolecular and Materials Chemistry 11 Medical and He. J Nanobiotechnol. 2018;16:1-33.

98. Mura S, Nicolas J, Couvreur P. Stimuli-responsive nanocarriers for drug delivery. Nat Mater. 2013;12:991-1003.

99. van Elk M, Murphy BP, Eufrásio-da-Silva T, O'Reilly DP, Vermonden T, Hennink PWE, Duffy GP, Ruiz-Hernández E. Nanomedicines for advanced cancer treatments: TRANSITIONING towards responsive systems. Int J Pharm. 2016:515:132-64.

100. Jahangirian H, Lemraski EG, Webster TJ, Rafiee-Moghaddam R, Abdollahi Y. A review of drug delivery systems based on nanotechnology and green chemistry: green nanomedicine. Int J Nanomed. 2017;12:2957-78.

101. Bae Y, Nishiyama N, Fukushima S, Koyama H, Yasuhiro M, Kataoka K. Preparation and biological characterization of polymeric micelle drug carriers with intracellular pH-triggered drug release property: Tumor permeability, controlled subcellular drug distribution, and enhanced in vivo antitumor efficacy. Bioconjug Chem. 2005;16:122-30.

102. Cheng N, Hu Q, Guo Y, Wang Y, Yu L. Efficient and selective removal of dyes using imidazolium-based supramolecular gels. ACS Appl Mater Interfaces. 2015;7:10258-65.

103. Wang G, Ma Y, Wei Z, Qi M. Development of multifunctional cobalt ferrite/graphene oxide nanocomposites for magnetic resonance imaging and controlled drug delivery. Chem Eng J. 2016;289:150-60.

104. Yang K, Liu Y, Liu Y, Zhang Q, Kong C, Yi C, Zhou Z, Wang Z, Zhang G, Zhang Y, et al. Cooperative Assembly of Magneto-Nanovesicles with Tunable Wall Thickness and Permeability for MRI-Guided Drug Delivery. J Am Chem Soc. 2018;140:4666-77.

105. Liu G, Zou J, Tang Q, Yang X, Zhang Y, Zhang Q, Huang W, Chen P, Shao J, Dong X. Surface modified $\mathrm{Ti}_{3} \mathrm{C}_{2}$ MXene nanosheets for tumor targeting photothermal/photodynamic/chemo synergistic therapy. ACS Appl Mater Interfaces. 2017;9:40077-86.

106. Gong Y, Wang Z, Dong G, Sun Y, Wang X, Rong Y, Li M, Wang D, Ran H. Low-intensity focused ultrasound mediated localized drug delivery for liver tumors in rabbits. Drug Delivery. 2016;23:2280-9.

107. Mu Q, Wang H, Gu X, Stephen ZR, Yen C, Chang FC, Dayringer CJ, Zhang M. Biconcave carbon nanodisks for enhanced drug accumulation and chemo-photothermal tumor therapy. Adv Healthcare Mater. 2019;8:1-12.

108. Mei L, Zhu S, Yin W, Chen C, Nie G, Gu Z, Zhao Y. Two-dimensional nanomaterials beyond graphene for antibacterial applications: Current progress and future perspectives. Theranostics. 2020;10:757-81. 
109. Li J, Wang G, Zhu H, Zhang M, Zheng X, Di Z, Liu X, Wang X. Antibacterial activity of large-area monolayer graphene film manipulated by charge transfer. Sci Rep. 2014;4:87.

110. Akhavan O, Ghaderi E. Toxicity of graphene and graphene oxide nanowalls against bacteria. ACS Nano. 2010;4:5731-6.

111. Chernousova S, Epple M. Silver as antibacterial agent: Ion, nanoparticle, and metal. Angewandte Chemie - International Edition. 2013;52:1636-53.

112. Lemire JA, Harrison JJ, Turner RJ. Antimicrobial activity of metals: Mechanisms, molecular targets and applications. Nat Rev Microbiol. 2013;11:371-84.

113. Li Y, Zhang W, Niu J, Chen Y. Mechanism of photogenerated reactive oxygen species and correlation with the antibacterial properties of engineered metal-oxide nanoparticles. ACS Nano. 2012;6:5164-73.

114. Lu Y, Qu X, Zhao W, Ren Y, Si W, Wang W, Wang Q, Huang W, Dong X. Highly stretchable, elastic, and sensitive MXene-based hydrogel for flexible strain and pressure sensors. Research. 2020;2020:2038560.

\section{Publisher's Note}

Springer Nature remains neutral with regard to jurisdictional claims in published maps and institutional affiliations.

- fast, convenient online submission

- thorough peer review by experienced researchers in your field

- rapid publication on acceptance

- support for research data, including large and complex data types

- gold Open Access which fosters wider collaboration and increased citations

- maximum visibility for your research: over 100M website views per year

At BMC, research is always in progress.

Learn more biomedcentral.com/submissions 